\title{
AUTOCREACIÓN Y FORMAS AUTOBIOGRÁFICAS EN LA PRENSA CRÍTICA DEL SIGLO XVIII
}

\author{
Inmaculada URZAINQUI \\ Universidad de Oviedo
}

Entre los muchos hilos que entretejen la novedad del Siglo de las Luces, uno que se of rece con trazos particularmente vigorosos y representativos, tanto por su diseño como por su proyección en la vida intelectual y social del momento, es el de la prensa periódica, una actividad que ya para los contemporáneos representaba, como constata el abate Juan Andrés cuando llevaba ya bastante camino andado, "una nueva clase de literatura, una nueva ocupación de los literatos, y un nuevo ramo de comercio literario y económico" (1793, VI, pág. 165). Aunque había tenido su comienzo con las gacetas informativas aparecidas en las últimas décadas del siglo anterior (de las que sólo quedó la Gaceta de Madrid, iniciada en 1661) se trataba, efectivamente, de una institución cultural que, con su carácter y expectativas de difusión, había modificado sustancialmente el paisaje intelectual y literario de nuestro país, ofreciendo un instrumento de comunicación de posibilidades nunca sospechadas hasta entonces.

Al compás de su propio desenvolvimiento, fue definiendo un territorio propio que desde el principio estuvo marcado por el sello de la diversidad; diversidad de fórmulas y diversidad de estrategias expositivas, pues a la información política, que fue con la que dio sus primeros pasos, muy pronto se unieron la información cultural, la difusión literaria, la crítica social y bibliográfica, etc.

De entre ellas, una que tuvo particular arraigo y personalidad fue la de ensayismo crítico, que había tenido su nacimiento y primer desarrollo en Inglaterra con los conocidos The Tatler (1709) de Steele, The Spectator (1711) de éste y Addison y The Guardian (1713) de Steele también, muy pronto vertidos y adaptados al francés y al italiano. Los escritores que la cultivaron, aquí, como antes en Inglaterra, comprendieron las ventajas que para sus objetivos ofrecía el discurso breve, aparentemente informal, sin aparato biblio- 
gráfico y teñido de fuerte subjetivismo: el molde estructural que luego, ya bien entrado el siglo XIX, acabaría en España por llamarse ensayo.

En su diseño entraba, de acuerdo con los modelos ingleses, la conformación de una estructura autobiográfica múltiple, integrada, de una parte, por la delineación de un yo que sirve de soporte expositivo y que va cobrando bulto y matices a medida que va desarrollándose en su andadura literaria, y de otra, por las diversas voces incorporadas en forma de corresponsales, reales o ficticios, o mediante otros procedimientos, a las que se va dando cabida para acentuar y multiplicar la carga crítica dilatando el espacio narrativo, y cuya personalidad puede ser también desplegada con trazos vivos conformando incluso unidades narrativas muy afines al relato breve. La introducción de todas ellas permite a los periodistas soslayar el tratamiento puramente discursivo de los temas que, abordados por perspectivas vitales diferentes a la suya, cobran un vigor crítico de superior calado, consiguiendo de paso hacer mucho más variada y viva la obra. La eficaz funcionalidad de estas piezas - mayor variedad, actuar como introducción para sus reflexiones, salvaguardar la dignidad de su condición de espectador, mayor libertad para conocer la reacción del público ante la introducción de nuevas ideas- había sido luminosamente expuesta por el Spectador al confesar en su n⿳2 542 ser él mismo el autor de muchas de ellas. El resultado es una singular polifonía de matriz seudo-autobiográfica definida por la voluntad creativa del propio periodista, muy próxima al territorio de lo novelesco, aun cuando en algunos casos ciertos rasgos del yo protagonista y del resto de las voces integradas pueden responder a circunstancias y variedades caracteriológicas sustentadas en la realidad. En cualquier caso, se trata de un tipo de fórmula singular, difícil de apresar en una modalidad genérica específica, porque el ámbito en el que se mueven está marcado radicalmente por su naturaleza proteica, híbrida. Desde luego, no se trata de estructuras autobiográficas en sentido estricto, aun cuando tanto en un caso como en el otro parezca existir un sujeto autobiográfico en el que se reúnen autor, narrador y personaje principal biografiado, según lo que se viene proponiendo como elemento constitutivo para tales composiciones (Lejeune, 1975, 1991; Bruss, 1991). Para serlo tendría que ser un ejercicio de memoria personal, que sólo se da, real o ficticiamente, en las cartas remitidas a la revista y no en el autor, que sólo muy de cuando en cuando introduce alguna confesión de su presunto pasado. Tampoco son estructuras autobiográficas enteramente ficticias, porque hay razones para creer que, al menos, ciertos ingredientes que definen esos sujetos autobiográficos, remiten a personajes y caracteres reales. $\mathrm{Y}$, obviamente, tampoco son estructuras novelescas en sentido propio, porque sólo ofrecen desarrollos ficcionales muy embrionarios y sus personajes no se hallan articulados dentro de un mundo esencialmente ficticio. Se trata, en cualquier caso, de una original forma de composición definida por una doble perspectiva autobiográfica, la del autor y la de los sujetos incorporados a su palabra crítica, y por una tendencia de aproximación hacia el mundo de lo novelesco.

Este registro personalista que acoge el periodismo del XVIII (y que no remite exclusivamente a un origen inglés, dándose también otras influencias y 
matrices, como la epistolografía precedente, los escritos de crítica social de Quevedo, la oratoria, los ensayos de Feijoo o aun, en algún caso, aunque no se mencionen, los textos autobiográficos de Torres Villarroel, con sus elementos bufonescos y degradatorios) se materializa en un crecido número de publicaciones que entre todas conforman una arquitectura crítica protagonizada por voces y puntos de vista diversísimos: El Duende crítico, El Duende especulativo sobre la vida civil, El Murmurador imparcial, El Belianís literario, El Escritor sin título, El Pensador, La Pensadora gaditana, El Corresponsal del Pensador, El Censor, El Apologista Universal, El Observador, El Corresponsal del Censor, El Teniente de Apologista universal, El Duende de Madrid, El Corresponsal del Apologista Universal y El filósofo a la moda, sin citar la multitud de cartas que con elementos autobiográficos se ofrecen en otros periódicos misceláneos de la época como El Memorial literario, el Diario de Madrid, el Correo de los Ciegos, etc.

Como se desprende de los mismos títulos, cada uno se ofrece y presenta al público desde una personalidad o desde una actitud psicológica dominante: pensador, murmurador, censor, observador, apologista, etc. Tres de ellos optan por la figura de un duende, continuando de algún modo una línea ya consolidada en la narrativa española con ficciones como la de El diablo cojuelo de Vélez de Guevara; otros tres por la de corresponsales de un periódico con el que establecen una singular sintonía crítica, uno por la de ayudante suyo ( $E l$ Teniente del Apologista Universal), otro por la humorística de un Escritor sin título, otro por la de un filósofo, y otro, por último, por la de un caballero andante, El Belianís literario. Algún otro periódico podría hacer pensar por su título -v.gr. El Hurón político, El Hablador juicioso, El Pensador cristiano, El Poeta, El erudito investigador o El Regañon general- que se trata de publicaciones con este carácter; pero no es así, porque les falta este rasgo de autocreación que venimos proponiendo como carácter fundamental de esta dirección crítica.

La lectura de los textos evidencia que esta elección de título no es gratuita, sino que sus autores, hurtando su personalidad privada, se enmascaran tras la figura que les ofrece más posibilidades de proyectar sus objetivos críticos siempre variaciones de una invencible actitud de observación y de crítica- y con la que tratan de acomodarse en su desarrollo sosteniéndola de manera congruente. El Censor, que se distinguirá por su lúcida reflexión sobre la singular condición de esta modalidad critica, lo formula con precisión en el discurso 137 , verdadera poética del género, cuando dice:

Quiérese que los caracteres que se describen se presenten en toda su extensión: quiérese que cada discurso sea una especie de tratado [...]. El autor debe, por una parte, sostener en toda la obra el carácter que de una vez se ha revestido, y por otra, debe, para darla variedad, transformarse a cada paso en diversos personajes, cuya introducción haga el mismo efecto que en un drama o en una epopeya los episodios (pág. 87)!

1. El subrayado es nuestro; lo mismo en los sucesivo salvo indicación en sentido contrario. 
Hay, pues, al menos en los más conscientes, según se desprende de este texto, un designio de ofrecer caracteres convincentes; tanto el elegido por el propio autor para "revestirse" de él como personalidad dominante, como de los introducidos para dar variedad a la obra y que él, con instinto literario, compara con los episodios de un drama o de una epopeya. Y ciertamente, aun cuando en algunos casos se adviertan ciertas fallas que impiden considerar sus soportes autobiográficos como personalidades compactas y acabadas, la fórmula periodística tiende a ello, de modo que el lector habitual de la publicación tiene la impresión de estar asistiendo al desarrollo de una personalidad intelectual cuyos rasgos definitorios se le van ofreciendo en las entregas sucesivas. Los fundamentales suelen aparecer enunciados en el primero de los discursos, como base del pacto de comprensión cordial que el autor busca establecer con el público. El periodista quiere que los lectores sepan quién les habla y qué objetivos persigue; trata de obtener de ellos una respuesta afectiva asociándolos a su tarea creativa y crítica; y para ello se lanza a un ejercicio de autocreación, de autorretrato, ya desde la primeras páginas, complaciéndose en dibujar los rasgos caracterizadores de su propia imagen (Un dibujo -importa advertidocon frecuencia tamizado por el filtro de la ironía, recurso casi consustancial con el género²). Escribe así, por ej. Clavijo y Fajardo en El Pensador:

Señor Público. Vm. no gustará de que se le presente una obra periódica sin prevenirle el motivo que ha tenido el autor para escribirla, el objeto que se propone en ella, el método que ha de seguir en su ejecución, el tiempo en que debe salir a luz, y lo que es más: las circunstancias agravantes de si el autor es blanco o tinto, grande o pequeño, de genio dulce o de complexión biliosa, cosa tan importante para su inteligencia. Sobre todo quiero satisfacer la curiosidad de $\mathrm{Vm}$. y a esto se reduce mi prólogo.

Yo, señor mío, soy de genio taciturno y nimiamente delicado [...| Pero falta lo más esencial (dice Vm.) que son las calidades y circunstancias del obrero. Poco a poco. Aunque no me vendo, y que por consiguiente nada le importa a $\mathrm{Vm}$. mis calidades, quiero que seamos amigos, y es preciso empezar por darle gusto... ${ }^{3}$.

\section{Y El Censor:}

Había pensado comenzar este discurso de un retrato mío, porque me pareció siempre muy juicioso y muy digno de ser imitado el cuidado que tienen muchos escritores de informar a público de sus facciones, y trasladar a la posteridad su figura. En efecto, es ésa una cosa que puede dar mucha luz paz la inteligencia de sus obras: y además, no se puede negar que causa mucha desazón esto de escuchar las razones de un hombre sin verle la cara. Por esta razón no me descuidé yo en hacer dibujar la mía por un artífice bastante diestro. Pero no necesité más que ver su obra para mudar enteramente de ánimo.

2. «El campo más fértil para la pluma en este país de la moral filosofía, es -dice El Duende especulativo- la ironía; pues sólo ella pude con precisión, tejer el lienzo para representar a lo natural las costumbres y abusos que hacen los hombres de sus talentos» (pág. 119).

3. Para redactar estas páginas, no se me ha sido posible disponer de la primera edición. Cito por la reedición barcelonesa de Francisco Generas, El Pensador matritense (s.a.), en la que los 86 números originales aparecen refundidec en 70, mediante la reunión en algunos casos de dos en uno. Pero el texto, salvo alguna que otra alusión referida al ámbito catalán para el que se destina, es el mismo. 
Algo más que mi semblante me parece digno de la curiosidad del público mi carácter, que no deja de ser bastante extraño. Por otra parte, siendo una de las cosas que me propongo en esta obra representar los de otros que me parezcan particulares, es muy justo que empiece por el mio y que su descripción aparezca a la frente de todos ellos. Así procuraré trazar mi retrato moral en el presente discurso, que informando al mismo tiempo a mis lectores de los motivos que me han empeñado en ser escritor público, podrá servir de prólogo a los que se sigan (pp.18-19).

El periodista, en este ejercicio de autocreación, forja la semblanza del personaje-autor por cuya voz va a expresarse, o dicho de otro modo, crea una personalidad interpuesta que viene a asumir sus opiniones críticas. De algún modo recuerda la delineación que de su personalidad crítica traza Feijoo como "desengañador de las Españas", en feliz expresión de Marichal, aunque con una diferencia fundamental: que Feijoo habla por si mismo, aun cuando se halle revestido de un perfil singular, mientras que los periodistas la corporeizan con un grado superior de ficcionalidad, siguiendo, de cerca o de lejos, las propuestas del Spectator ( $\mathrm{n}^{\circ}$ 55), quien -como recuerda Escobar (1982, pp. 483) - ya había advertido que la comunicación con el público resultaba mucho más fácil desde un carácter fícticio que desde el verdadero del propio autor: razón por la cual muy pocos son los que estampan su nombre real al frente de la publicación.

De tenor más genuinamente autobiográfico, por lo que pueden tener de confesión-evocación, de descubrimiento de la propia interioridad y de esfuerzo comprensivo del presente en tanto que resultado de un pasado-siquiera en esbozo- son las cartas o los documentos pseudo-personales incorporados al texto. Muchos de ellos empiezan con un expresivo "Yo soy..." que va a enmarcar confesiones -amargas o festivas-, miradas retrospectivas, inculpaciones o exculpaciones, interpretaciones de la propia existencia, etc., a través de los cuales el escenario social al que el periódico remite se despliega y concreta en actitudes y situaciones variadísimas. Al mismo tiempo, estas historias, al encuadrarse en un contex to crítico-reflexivo como elemento de argumentación, se elevan a una dimensión ideológica superior, bien por avenencia con las ideas sustentadas, bien por contraste con ellas. Su funcionalidad, aunque en un contexto genuinamente secularizado, viene a coincidir así de algún modo con la tradición del exemplum y de la literatura de casos ejemplares.

La carta, como he dicho, es el vehículo más frecuentado para este tipo de actos autobiográficos. Pero hay también algunas otras formas. En El Pensador, Clavijo y Fajardo incorpora un elocuente fragmento de diario, al tratar de la necesidad de aprovechar bien el tiempo. Convencido de la eficacia que para evitar su pérdida tendría el que los hombre se dedicasen a llevar uno exacto de sus acciones, trató - dice- de persuadir a varias personas para que hicieran el ensayo. Poco tiempo después le llegó el de un empleado de oficina, muy largo, del que transcribe una semana, con el objeto, -resulta obvio- de constatar cómo puede pasarse la vida en futilidades y naderías. Así, empieza el primer día, domingo, 11 de Enero: "Me levanté a las nueve. Viento norte. De nuevo a 
nueve y media tomé chocolate, y me lavé. Me estuve a la copa hasta la diez, que vino el peluquero. Dice que la viudita de la calle de Alcalá va viento en popa con su galanteo...". Es un texto dei mayor interés para comprender las coordenadas ideológicas en que se moverá la redacción de los primeros -y posteriores en el tiempo-diarios españoles de Moratín, Jovellanos, etc. (R. y M. Andioc, 1967, pág. 11).

En algún caso las cartas tienen un destinatario distinto del propio periodista, quien las da al público en forma semejante a como lo hace Cadalso con los corresponsales de sus Cartas marruecas (publicadas, recordémoslo, póstumamente en el Correo de los ciegos), En El Pensador sale la de Ibrahim Ali Golou ( $\left.\mathrm{n}^{2} 44\right)$ y en El Censor las de un marroquí, viajero recientemente por España, a su amigo Abu Taleb (núms. 65 y 87) y las paródicas de Mr. Ennous, viajero en la Cosmosia, a Mister Seauton (núms. 89 y 90 ) sobre las costumbres e ideas de este país imaginario, aunque el perfil de los emisores no se ofrezca corporeizado en una personalidad definida. Su presencia está en función de la crítica de contraste que pueden ofrecer como miembros de una comunidad cultural ajena a la española.

Las virtualidades autobiográficas del diálogo o del monólogo se exploran también con buena fortuna. Así, en su número 53, transcribe El Pensador el largo y enfurecido monólogo de un hombre desbordado por el frenético despilfarro de su mujer, la cual aparece después reclamando insaciable más dinero; al final, el Pensador se retira por no ver cómo termina la agria conclusión. Otra conversación, esta vez entre una caballero europeo y un canadiense criado suyo, da pie a que este último, Sam, haga una extensa y vívida relación de su andanzas y vicisitudes hasta llegar a su situación presente ( $\left.\mathrm{n}^{2} 32\right)$.

Un papel caído al desgaire puede ofrecer también singulares confesiones autobiográficas. Este es el caso del que, paseando por Madrid, recoge El Pensador de un transeúnte que había volcado en él toda la angustia existencial derivada de una invencible obsesión por su salud (n⿳ 36 ) o el que recoge $E l$ Corresponsal del Censor, escrito en un idioma extranjero y que él traduce, conteniendo el relato de un náufrago sobre la singular e ilustrada existencia de los habitantes de la isla a la que arriba (núms. 20 y 21 ). Otras veces, el relato llega a través de la compra de un manuscrito, como el de la monarquía de los Ayparchontes, escrito también en primera persona y en registro utópico, supuestamente comprado por El Censor, junto con otros más, en una librería madrileña, y que publica a lo largo de los discursos 61,63 y 75 , ofreciendo la fascinante experiencia del encuentro con un mundo desconocido y admirablemente bien organizado. En el caso de estos dos últimos, su estructura se acompasa dentro del molde genérico, afín al territorio de lo novelesco y muy frecuentado en la época, del viaje imaginario.

En clave fantástica se ofrecen también algunas otras modalidades pseudoautobiográficas. En el mismo Censor el rechazo por el uso literario de la mitología, en lugar de defenderse mediante un escrito discursivo como el que, por ejemplo, publicará poco tiempo después J.L.M. en el Memorial literario, se 
envereda a través de un edicto que la Razón y el Buen Gusto le remiten por mediación de Fidelio, Secretario del consejo del Parnaso, a través del cual, en tono apasionadamente personalista, piden que las divinidades paganas (Mercurio, Vulcano, Minerva, etc.), cansadas ya de su dilatada ejecutoria de servicio y obligados a trabajar inhumanamente como "cuando estaban en lo más florido de su edad", sean relevadas de sus funciones y pasen a una situación de jubilación definitiva (disc. 16, pág. 237). En parecida línea, el mismo Censor publica en su $\mathrm{n}^{\circ} 32$ una durísima crítica al deplorable estado de la literatura contemporánea en forma de una sentencia, también muy personal y vehemente, de "D. Apolinar Solano", juez del Parnaso para la provincia de España. El sueño alegórico -a fin de cuentas, expresión de un experiencia (ficticia) personal- y cuyos perfiles remiten a una tupida red de tradiciones literarias (entre ellas, la del propio Spectator), aparece ya desde el Duende especulativo sobre la vida civil (el difícil camino hacia el templo del honor, $\mathrm{n}^{0} 15$ ). El Pensador contiene sólo uno: la historia de la transformación de Fidelio en espejo ( $\mathrm{n}^{\circ}$ 66), que proviene, como ha señalado Guinard, del $\mathrm{n}^{\circ} 392$ del Spectator (1973, pág. 180). La Pensadora gaditana sueña que comparece ante el tribunal de la verdad ( $\left.\mathrm{n}^{2} 7\right)$. En El Censor se relatan varios, suyos o de algún familiar, como el de su padre, muy proclive a estos ejercicios, que permite al periodista reflexionar sobre los funestos efectos del error y la vanidad en el mundo ( $\mathrm{n}^{\circ}$ 69). En El Observador, Marchena relata el que le condujo a conocer la existencia y modo de vida de los selenitas o habitantes de la luna (no 4) y en El filósofo a la moda el que le permitió asistir a la disección del cráneo de un petimetre y una desvanecida $\left(\mathrm{n}^{\mathrm{0}} 36\right)$.

Ahora bien, sea una u otra la forma elegida, es obvio que el registro personalista, la escritura en primera persona, se demostró como una opción expositiva mucho más grata a los periodistas (y en consecuencia, al público para el que escribían) y con muchas más posibilidades críticas que el discurso o el tratado en tercera persona. Una de las principales causas de ello ha de buscarse -no parece aventurado proponerlo- en la misma que determinó la extraordinaria eclosión de escritos autobiográficos en toda Europa y que ya apuntó Gusdorf en su fundamental y pionero trabajo sobre el tema (1948): en la corriente de individualismo y de conciencia de la personalidad que, originada en el Renacimiento, alcanzó su plenitud en el siglo de las Luces, y que orientó la expresión de la cultura y de la literatura por los caminos del subjetivismo. Aunque en su caso no se trate de autobiografías reales, el hecho de servirse de sus esquemas descansa en el mismo gusto por lo personal en que aquéllas se incardinan. O lo que es lo mismo, unas y otras son expresión y realización del espíritu moderno. El mismo que alentó el gusto por el ensayo como alternativa, más eficaz y literaria, frente al discurso escolástico y académico (Bueno, 1966), apto ante todo para minorías intelectuales y no para el común de las gentes -el "grueso de la Nación", en expresión de El Corresponsal del Censor -que era al que los periodistas dirigían sus escritos. Era un camino nuevo para establecer relaciones de proximidad con el lector, de acortar distancias, de impregnar con tonalidades individuales la escritura, de dotarla de un mayor 
compromiso con la actualidad, de bajarla del olimpo de la especulación impersonal a la llanura de la contemporaneidad, de hacerla también más literaria; en suma, de avanzar por el camino de la secularización y de la modernidad ${ }^{4}$. Erá también una forma de plasmar -y legitimar- el derecho a expresar, desde la propia razón individual, la crítica pública. El modelo de la prensa inglesa, con el Spectator a la cabeza, hizo el resto.

El Duende crítico fue el pionero de este tipo de escritos, aunque por su singulares características forma un universo propio que poco o nada tiene que ver con el resto. Su existencia no traspasó el ámbito manuscrito y su carga crítica se enderezó fundamentalmente hacia la política contemporánea. Salió cada jueves desde Diciembre de 1735 hasta Mayo de 1736, prodigándose inmediatamente las copias (con infinidad de variantes) y las imitaciones5. Ejemplar típico de literatura clandestina que representaba a un sector social de descontentos y cuyas quejas se vertían en moldes muy parecidos a los suyos, fue obra del capuchino portugués fray Manuel Freyre de Silva (fray Manuel de San José en religión) y algún colaborador más o menos ocasional (Egido, 1968). Se ofreció al público, según reza el comienzo del primer número, bajo la máscara de "un crítico duende", una personalidad particularmente propicia para reflejar, tanto su movilidad inspeccionadora como condición inasible, y para amparar su verdadera identidad. La actualidad en que la ironía de Feijoo había colocado este mundo de trasgos, duendes y espíritus familiares le facilitaba, como ha señalado Teófanes Egido, su aceptación por el público. El texto de la introducción lo proclama abiertamente: "Yo soy en la Corte / un crítico duende / que todos me miran / y nadie me entiende. / Cuando meto ruido / en el Gabinete / asusto a Patiño / y enfado a los Reyes. / Como no me miran / aunque me ven siempre / ni saben quien soy / ni saberlo pueden. / Yo sé los secretos / de sus intereses / y sé que se engañan / recíprocamente...". Su registro habitual es el de la sátira, una veces feroz, incluso grosera, y otras más irónicamente festiva. Y es éste el que lleva toda la atención de su autor. El soporte personal del duende funciona ante todo como una voz, como un introductor de textos críticos de la más variada índole (parodias de catecismo, diálogos, pronósticos, reprensiones, recetas, etc.). -casi siempre en verso- $\sin$ que apenas importen los contornos de su talente y figura. Lo esencial está apuntado en la introducción, aunque luego, a lo largo de sus números, se desgranan algunas otras referencias caracterizadoras: es "alegre y travieso" (pág. 5), celoso del bien público, invisible, sutil, penetra las conciencias, bueno, con dotes poéticas; no

4. Terminadas estas páginas, llega a mis manos el libro de Javier de Prado, Juan Bravo Castillo y María Dolores Picazo, Autobiografía y modernidad literaria, Cuenca, Ediciones de la Universidad de Castilla-La Mancha, 1994, con el que me complace afirmar hay una coincidencia básica de criterios en este punto, que ellos desarrollan con profusión de textos y sagaces conside. raciones críticas. No obstante, la consideración de la prensa de carácter autobiográfico queda fuera.

5. Para los datos fundamentales de este periódicos, como para los que se citan a continuación, vid. las obras citadas en la Bibliografía de F. Aguilar Piñal, P.F. Guinard y M. D. Saiz.

6. Cito por uno de los ms. del Duende (A) existentes en la Biblioteca del Instituto Feijoo de Estudios del Siglo XVIIl, de Oviedo. 
se mete con las damas porque "es muy caballero" (pág. 6), no quiere recompensa ni venganza, sólo la equidad y la verdad (pág. 4); es "un duende de honor / de provecho y pasatiempo / de España procurador / y en la comedia del tiempo / el Duende predicador" (pág. 32). Vive en un desván, donde se relaciona con otros espíritus o trasgos y aun con el mismísimo Diablo Cojuelo, con el que mantiene una larga conversación (pp. 121 y ss.). Indudablemente, sus raíces ideológicas y literarias están en el literatura satírica y clandestina del siglo XVII, antes que en la inglesa, si bien -todo hay que decirlo- esta última también tuvo una importante deuda con aquélla en la configuración del personaje que se entromete en todo - con el Diablo cojuelo de Vélez de Guevara especialmente-a través de la adaptación francesa de Lesage (Hendrix, 1991-1922; Escobar, 1982).

El siguiente -veinticinco años después- quiso ser también duende, pero con una dimensión y un carácter enteramente distinto: El Duende especulativo sobre la vida civil, publicado entre el 9 de Junio y el 26 de Septiembre de 1761 con un total de 19 números. Apareció como "dispuesto por don Juan Antonio Mercadal", nombre tras el que los primeros historiadores de la prensa quisieron ver el seudónimo del más prolífico periodista de la centuria, Francisco Mariano Nifo, y más recientemente, Paul F. Guinard, con buenas razones, el del holandés afincado en España, Juan Enrique de Graef, buen conocedor de los espectadores extranjeros (1973, pág. 153) e iniciador de la prensa económica con sus Discursos mercuriales. Tiene el gran interés de ser la primera imitación española de los espectadores ingleses y franceses, de los que toma-como ya señaló Guinard-muchos pasajes y aun números enteros, adaptándolos a la vida y circunstancias de la España de entonces, de acuerdo con el frecuente proceso de nacionalización que opera en las traducciones contemporáneas. Como indica su título, su voz crítica se manifiesta a través de la de un duende al que, por serlo, le es permitido adentrarse por todos los rincones del Madrid de la época: paseos, iglesias, lugares de reunión... Persigue, ante todo, la crítica de la vida social madrileña desde el privilegiado observatorio de un espectador oculto ("sentado como en una cámara oscura en medio del público, sin ser conocido ni observado de nadie" (n" 1 , pág. 18), al que ayudan varios miembros de una tertulia), ámbito desde el que también se ofrecía la voz crítica del Spectador inglés ( $\left.n^{2} 2\right)$, y a las que también se unirán, como será habitual en estos periódicos, las de distintos corresponsales imaginarios que, desde su situación particular, concurrirán a desplegar diferentes matices de los temas incriminados.

El Murmurador imparcial y observador desapasionado de las locuras y despropósitos de los hombres de Nifo, fue una efímera publicación que salió en ese mismo año de 1761. No parece que pasara de la introducción y el número 1 , que es lo único que he visto. Pese a lo prometedor del título, el deseo de ilustrar sus observaciones críticas con textos de autores españoles del siglo anterior se impone sobre la crítica propiamente dicha, y lo convierte en un periódico muy afín al antológico Cajón de sastre, que hacía muy poco había publicado también él. En principio, quería ser un instrumento para desterrar, por medio de la crítica humorística, la meledicencia: "manifestar cómo ha de proceder la murmuración para no desviarse del camino de la caridad", atacando el vicio 
desde distintos puntos de vista. Pero apenas se resuelve en un mediocre ensayo de crítica social, condensado en la "Observación primera: los murmuradores y las visitas", quedando su condición de murmurador en mero soporte nominal, sin más rasgos individualizadores. Es una producción que se ahija, antes que en la inglesa -que Nifo no parece conocer sino muy superficialmente (Guinard, 1973, pág. 177) - en la línea crítica quevedesca.

Salvado este frustrado intento de periódico crítico, un año después aparece, siguiendo la senda del Duende especulativo, o mejor, de la prensa inglesa, El Pensador de Clavijo y Fajardo, un brillante intelectual de origen canario, formación francesa y estrechamente vinculado a la Fonda de San Sebastián, impulsado por un irrefrenable propósito de "reformar sus españoles, que es lo que más le duele, como verdadero patricio" ( $\left.\mathrm{n}^{\circ} 46\right)$. Sus 86 números, titulados 'Pensamientos', se publicaron en dos etapas; los primeros 52 salieron con bastante regularidad entre Septiembre de 1762 y el mismo mes de Octubre al año siguiente (según se desprende de los anuncios de la Gaceta), y tras un paréntesis de casi cuatro años, cuyas causas todavía no se han aclarado satisfactoriamente (Caso, 1990, pág. 100), reapareció en Febrero de 1767, año en que salieron los 34 restantes. La solicitud y los primeros números los suscribió con el seudónimo de "José Álvarez y Valladares", y a partir del segundo tomo con el suyo propio. Aunque no hay duda de que la obra es enteramente suya, no es impensable que colaboraran con él otras personas. El viajero inglés Richard Twiss se hace eco de la atribución de una parte de ella al mismísimo ministro Wall (Guinard, 1973, pág. 177) y J.M. Caso González ha sugerido recientemente la posibilidad de una colaboración directa de Nicolás F. de Moratín en razón de su identidad de ideas en materia de teatro (1990, pág. 100); pudiera ser, pero por el momento no hay prueba documental ni sobre lo uno ni sobre lo otro. Lo que sí es evidente es que contó con la aprobación y el apoyo de Carlos III, según se desprende del texto del privilegio que le concedió el 1 de febrero de 1763 (figura al frente del tomo III), coincidiendo con su nombramiento como oficial del archivo de la Secretaría de Estado.

La revista es, como su título indica, y como el autor se encarga de delinear en su propio autorretrato, la expresión crítica de un hombre profundamente reflexivo; amigo de leer y de escribir; de genio taciturno y silencioso aunque no indolente; irritable, pero no rencoroso ni vengativo; falto de ambiciones políticas; patriota y monárquico; un tanto engreído y pagado de sus opiniones; ansioso por ser útil y, por encima de todo, un observador impenitente de todos los rincones de la sociedad que, sensible en extremo ante todo to que la perturba, decide desahogar su rabia e indignación haciendo partícipe a sus lectores de sus propios "pensamientos". Son trazos que expone con su habitual estilo, sugestivo y brillante:

Yo, señor mío, soy de genio taciturno, pensador y nimiamente delicado. La menor costilla en orden a las costumbres, a la política, al idioma, o cualquiera de aquellas que miran a la sociedad, a la vida, a las artes y a las ciencias excita mi imaginación, y sin saber cómo ni por donde, me hallo a cada instante con el cerebro lleno de ideas, que unas veces me alegran y otras me entristecen, y siempre tienen en 
ejercicio mi pensamiento. Lo peor del caso es que por aquel rato que me dura el entusiasmo (que no son pocos) todo cuanto pienso me parece excelente: me miro como el primero de los hombres; deploro la suerte de éstos en no tenerme por su guía, y llega mi desvanecimiento hasta creer que podría contribuir a su felicidad. En esta divertida manía paso la mayor parte de mi vida, siempre pensativo y casi siempre sin salir de mi cuarto. A los principios se volvían mis pensamientos por el mismo camino que habían traído; llegaban otros que ocupaban el lugar de los primeros, y no despidiéndose éstos ni los que le seguían. Sin dejar sucesión se iban borrando en mi memoria, al arribo de los nuevos huéspedes las ideas que habían excitado sus abuelos. No le pareció bien este método a mi amor propio, que en cada especie olvidada creía haber perdido un tesoro. Mudé de sistema; empecé a trasladar al papel todas las quimeras y todas las necedades que pasaban por mi fantasía, y gracias a este cuidado, me hallo con un registro general de cuanto he pensado de algunos años a esta parte... $\left(\mathrm{n}^{\mathrm{o}} 1\right)$.

El mismo estilo informal y desembarazado que dice va a emplear, aunque responda sin duda a una opción estética premeditada, acorde con los objetivos que se propone, lo presenta como un fruto de su propio carácter:

No hay que buscar pulidez en mis pensamientos. Mi genio es poltrón: traslado al papel las ideas del modo que se me presentan, y si tuviera precisión de entretenerme en corregir o limar el estilo, renunciaría ante al ejercicio de escribir que sujetarme a la pesada materialidad de aquel trabajo (pág. 21).

De su aspecto físico nadie dice en este primer pensamiento. Lo hará en el 7 , respondiendo a la carta de un presunto corresponsal, "Santiago Curioso", que, paseando el día anterior por el Prado, creyó reconocer la figura del Pensador. Éste le dice que no pudo ser, porque ayer no salió a pasear; pero que, en todo caso, le dirá cómo es:

Yo soy pequeño y grueso, de modo que parezco un Sancho Panza. Tengo medianos colores y mis rasgos de petimetre. Lo pensador tampoco me sale al semblante, que tiene más de festivo que de serio. Con estas noticias y el retrato que se pondrá en la fachada de mis obras cuando se haga la décima o undécima edición, tendrá Vm. lo bastante para conocer a su servidor (pág. 168).

Algunos otros rasgos de su vida y personalidad irán saliendo de su pluma más adelante: que antes de que llegase a experimentar el humor pensativo que se apoderó de él, gustaba mucho de asistir a tertulias ( $\left.\mathbf{n}^{\mathrm{n}} 17\right)$; que no conoce Roma; que le gusta mucho la música y la poesía (ibid.); que su ánimo, al reprender la conducta de los hombres, es aprender a reformar la suya ( $\left.\mathrm{n}^{\mathrm{o}} 19\right)$; que es lector de prensa ( $\mathrm{n}^{\mathrm{0}} 20$ ), profundamente creyente ("yo soy no sólo cristiano, sino católico", $\mathrm{n}^{\mathrm{O}} 28$ ); que conoce poquísimas personas en la corte y son muy pocas las casas en las que entra (una de las razones por la que sus retratos no aluden a personas conocidas) ( $\mathrm{n}^{\mathrm{0}} 29$ ); no es tan humilde que le mortifiquen los elogios (ibid); es dichoso ( $\mathrm{n}^{\mathrm{a}} 40$ ), aunque pocos números después se contradiga diciendo que desde que se ocupa en pensar, todo lo que piensa se vuelve contra él "ya porque me martirizan como propios los males 
ajenos, ya porque deseando curar en ellos a los que los padecen gritan éstos contra el médico" ( $\mathrm{n}^{\mathrm{O}} 41$ ); gusta de recoger y guardar papeles curiosos y encontrados al azar ( $\left.n^{\circ} 44\right)$; no se acobarda con las críticas que le puedan hacer ( $\left.\mathrm{n}^{2} 46\right)$; ante la sugerencia de estar siendo excesivamente serio y circunspecto. se resuelve a ser más festivo en adelante (no 58 ). A completar estos datos que él da de si mismo concurren alguno de sus corresponsales, ponderando tal o cual nota de su actividad de pensador. Uno de ellos, por ejemplo, le reprocha que no salga a la palestra para defenderse de las calumnias que lanzan contra él y, anticipándose a lo que luego dirá El Censor de si mismo, compara su tarea con la del héroe cervantino calificándolo de "Don Quijote literario" y hace algunos juegos de palabras con su propio nombre ("sale en contra un follón malambruno y Vm. se mantiene firme en su Clavijeño, vendado los ojos, sufriendo llamaradas y aumazos...", $\mathbf{n}^{\mathrm{0}} 40$ ).

Los voces que en forma de carta o de otra estrategia narrativa asocia a la suya son muchas y muy variadas: un amigo de imaginación viva, humor bilioso y carácter irascible que se encrespa contra el cortejo (núms. 4 y 5); el (alegórico) visitador de los locos, que le da cuenta de las locuras de los hombres ( $n^{\circ} 6$ ); una muchacha hija de padres ricos y nobles que sufre las consecuencias de una educación frívola (núms. 8 y 67); un hombre dominado por su mujer $\left(\mathrm{n}^{\mathrm{Q}} 8\right.$ ); un americano que, recién llegado a Madrid, se asombra del estado de las representaciones teatrales $\left(\mathrm{n}^{\mathrm{9}}\right.$ 9); el también alegórico visitador de los cuerdos que se asombra de lo que las gentes tienen por tales $\left(\mathrm{n}^{2} 10\right)$; un español recién llegado de recorrer cortes sin ningún provecho, por haber planteado mal sus viajes ( $\left.{ }^{9} 19\right)$; un cura que se exaspera ante los sermones gerundianos del día ( $\left.\mathrm{n}^{\circ} 24\right)$; un peluquero preocupado por las cosas del teatro, afín en criterios al Pensador ( $\left.\mathrm{n}^{\circ} 29\right)$; un canadiense sensato e ingenuo que cuenta cómo llegó a ser criado de un caballero europeo ( $\mathrm{n}^{\mathrm{Q}} 32$ ); un viajero siamés que se extraña de los usos europeos (ibid.); un padre angustiado que se queja de la ingratitud de su hijo ( $\mathrm{n}^{\mathrm{g}} 33$ ); un hombre solitario y pensador pesaroso de su frívola juventud ( $\left.\mathrm{n}^{\circ} 34\right)$; un viudo desconsolado por la pérdida de su mujer ( $\mathrm{n}^{\mathrm{o}} 35$ ); un obseso ("valetudinario") por la salud $\left(\mathrm{n}^{\mathrm{Q}} 36\right)$; un recién llegado a la corte $\left(\mathrm{n}^{\mathrm{Q}} 37\right)$; un americano trasplantado a Madrid, frustrado en sus apetencias políticas ( $\left.\mathbf{n}^{\circ} 37\right)$; un lector de El Pensador para una tertulia de damas ( $\mathrm{n}^{2} 39$ ); un mahometano, Ibrahim Ali Golou, escandalizado por las prácticas religiosas que ve en España ( $\mathrm{n}^{\circ}$ 44); la diosa Fortuna (núms. 47 y 52); un petimetre engreído y satisfecho por haber llegado a serlo ( $\mathrm{n}^{\circ} 51$ ); un marido irritado por los excesos frívolos de su mujer ( $\mathrm{n}^{\circ} 53$ ); un aspirante al matrimonio indignado por las ceremonias y compromisos que suelen llevar aparejados las bodas ( $\mathrm{n}^{\circ} 55$ ) y por las absurdas etiquetas de los "refrescos" ( $\left.\mathrm{n}^{\mathrm{2}} 60\right)$; un peluquero que critica la frivolidad de las mujeres ( $n^{\circ} 55$ ); un hombre que lamenta la pésima educación que le dio al ayo que para él eligieron sus padres ( $n^{\circ} 58$ ); un hombre sencillo y cabal que en un baile se vio precisado a actuar como bastonero ( $\left.\mathrm{n}^{\circ} 59\right)$; un empleado de oficina que le envía el diario de su insulsa vida ( $\left.n^{\prime \prime} 63\right)$; dos opositores a cátedras ( $n^{0} 68$ ), etc.

En el conjunto de la revista, los asuntos tratados desde la voz del propio Pensador son muy pocos. Lo habitual es enmarcarlos en un contexto dual o 
polifónico. No siempre los personajes introducidos alcanzan a tener una personalidad perfilada o a ofrecer notas psicológicas de interés. Algunos son poco más que una voz. Otros, sin embargo, llegan a corporeizarse en tipos que tienen mucho de novelescos. Son personajes con carácter, con vida, con historia; sobre los que el periodista ha volcado su capacidad descriptiva, elevándolos a una categoría superior a la de simples soportes expositivos de una idea. Tal es el caso de la señor que habla de su proceso educativo $\left(\mathrm{n}^{\circ} 8\right)$; del padre angustiado por la ingratitud de su hijo, cuya patética historia narra con especiosos detalles ( $\left.\mathrm{n}^{\circ} 33\right)$; del viudo que evoca desgarrado la historia de su felicidad conyugal ( $\left.\mathrm{n}^{\circ} 35\right)$; del americano que llega a Madrid con pretensiones de hacer carrera política y cuya peripecia vital empieza con un expresivo "Yo soy un indiano de a pie, pobre y feo..." ( $\left.n^{\circ} 37\right)$; del bonachón metido a petimetre ( $\mathrm{n}^{\circ}$ 51), etc.

Cuando El Pensador llevaba ya varios meses de andadura, salió una réplica amistosa titulada El amigo y corresponsal del Pensador, de un enigmático Don Antonio Mauricio Garrido, que bien pudiera ser seudónimo de Nifo. Su vida fue muy efímera: apenas cuatro número o "cartas" formando un volumen de 110 páginas en 8\%. Representa la primera modalidad de periódicocorresponsal en el que el autor se configura como alguien que desea sugerir y desplegar ideas de otro que toma como referente, adoptando por ello una perspectiva en segunda persona. En su caso, éste es el único rasgo de autocreación que ofrece a los lectores. Por lo demás, los temas que trató en su corta existencia fueron muy afines a los tratados por El Pensador: filósofos de moda, abusos comunes, afeminamiento de las naciones, petimetres, etc. Este último aspecto de su crítica, planteado en la carta cuarta, lo forja como un cuento cuyo protagonista es Don Merengue, en quien materializa todos los aspectos negativos de este ridículo tipo.

Por entonces (mediados de 1763) apareció otra revista afiliada a la línea crítica, aunque con un carácter y objetivos muy distintos a los de los anteriores: El Escritor sin título que, humorísticamente, aparece como "traducido del español al castellano" "por el Licenciado D. Vicente Serraller y Aemor", seudónimo bastante transparente de su verdadero autor, el aragonés Cristóbal Romea y Tapia, cuyo nombre real aparece ya a partir del número 2. Su vida fue muy corta: apenas once números o "discursos". El esfuerzo autocreativo, bastante atenuado, se dirige a forjar la personalidad de "un español a prueba de bomba", de genio zumbón y malcontentadizo, dicharachero, proclive a un estilo "chocarrero y ordinariote" (pág. 295), polemista, aunque con ribetes de escepticismo, que sale al paso de los ataques que, según él, están haciendo a España y a la cultura española los periodistas críticos del momento ("hacer crítica de los que pretenden hacerla de todo" (pág. 6). Sus tiros los dirige inicialmente contra la sección de Noticias de moda del Diario extranjero (1763), de Nifo, centrada en la reseña de la vida teatral del momento, y luego contra El Pensador y contra los Desengaños al teatro español de Nicolás F. de Moratín, principalmente por sus críticas a los autos sacramentales; aunque reserva también una amplia parcela a la crítica de costumbres, en la que ofrece 
múltiples coincidencias con sus predecesores, incluido El Pensador, por el que sin duda sentía una gran estima, pese a sus discrepancias en materia teatral.

Aunque muchas zonas de su personalidad ficticia queden en la penumbra, se complace en ofrecer diversas pinceladas sobre su persona y aficiones, siempre en el tono desenfadado y burlón que le caracteriza, con juegos verbales y recursos degradatorios que recuerdan mucho la pluma del satírico Quevedo. "Yo que no soy, ni he sido, ni quiero ser pedagogo de nadie, ni mis lectores llevarían a bien verme de mal humor con un sermoncito moral entretejido de espolazos y torniscones..." (disc. 9, pág. 254) [...]. Mi genio es remolonazo y poltrón; mi madre no pare, y aunque para, no es a mi; pues cuchufletas, y a ello, no andarse en frioleras, salga pez o salga rana, que al cabo del mes lo mismo me den de un modo que de otro, y brava tripa hará un perro con un cantazo. Item, que Vm. según se pinta es un Pedro Fernández; y yo, aunque tan mamarracho como el que más, gustara de que cuando no tenga otra recompensa, suenen en mis escritos sujetos de carácter y gente de prosopopeya" (pp. 254-255). No le importa -o más bien se jacta-, de no saber francés, de escribir "para los tontos, siempre que ellos le paguen bien", de tener una nariz grande y de ser un pésimo poeta. "Llámole hermano [a Ovidio] porque soy tan Nasón como él, tan desterrado como hijo de Eva y tan poeta que puedo ser capuchino" (pág. 333). Gran admirador de Quevedo y Calderón, se confiesa también "ciego venerador del Platón de nuestro días [Feijoo]" (pág. 49). Todavía en el último de sus discursos, tras prometer volver a escribir un nuevo tomo, continúa, por medio de un romance, dando toques a la imagen que ha ido forjando de mi mismo:

... ¿Quién soy yo? No lo sé; pero pretendo/los más altos arcanos explicarte / pues sin saber el hombre de símismo/puede saber muy bien lo que no sabe./Pues ya sé quien soy: soy un compuesto / de piltrafas, de huesos, alma y carne / que en remediar el mundo estoy pensando / y por esto yo estoy sin remediarme. / [...] Demócrito también, quiero reírme / de tantos papelones como salen / y es risa que se rían los dolientes / hombre de los Peritos y Morales / capaz de gobernar toda la tierra / ¡Así fuera capaz de gobernarme [...]

Aunque estructuralmente prima en sus números el discurso, al igual que en $E l$ Pensador, da cabida también, para abordar los temas en clave más personalista y jugosa, a algunos diálogos y a una carta, la de un "D. Prudencio Renovado", quejándose de la vida ociosa de su mujer y de los muchos gastos de su cada, a la que contesta por extenso -humorísticamente- a lo largo de los números 9 y 10.

Casi a la par que El Escritor sin título comenzó a publicarse, primero en Madrid (los dos primeros tomos) y luego en Cádiz (los dos restantes), La Pensadora gaditana (1763, 52 núms.) de una "doña Beatriz Cienfuegos", gaditana residente en Madrid, sobre cuya enigmática personalidad todavía no se sabe nada con certeza. De espíritu muy afín al Pensador, aunque en tono más grave y moralizador, con una mayor carga religiosa, y desde una decidida perspectiva feminista, algunos contemporáneos, como Moratín (Sátira III, El Poeta, $\mathrm{n}^{\circ}$ 9, pág. 133), sospecharon que el verdadero autor era un religioso. Sea 
como fuere, uno de los aspectos que le da particular interés es el de haberse constituido en el primer periódico español hecho desde una perspectiva femenina y dirigido a mujeres principalmente (Kitts, 1990), aunque en este designio le había precedido algunas publicaciones extranjeras (Guinard, 1973, pág. 194). Haciendo gala de un feminismo batallador, aborda como asunto de sus incriminaciones muchos de los temas ya tratados por el Pensador, pero atendiendo particularmente a su concreción en los hábitos de las mujeres de su tiempo (el seguimiento de la moda, la ociosidad, la maledicencia, el cortejo, los matrimonios prematuros, la admiración inmoderada por lo extranjero, la mala educación de los hijos, etc.) y otros nuevos como las relaciones entre suegras y yernos, los placeres del campo, etc.

Se presenta ante los lectores como una mujer que goza la suerte de haber nacido en Cádiz, culta (destinada por su padres a la vida monástica -que no quiso seguir-, recibió una sólida formación filosófica), de espíritu libre, soltera ("libre de la sujeción del matrimonio"), valiente y decidida, que reivindica el derecho a dejarse oír y a ocupar un lugar en la sociedad, distinto al que tradicionalmente se ha otorgado a las mujeres, y con la edad suficiente para dar consejos acertados:

Alguna vez había de llegar la ocasión en que se viesen Catones sin barbas y Licurgos con basquiñas; no ha de estar siempre ceñido el don de consejo a las pelucas, ni han de hacer sudar la prensa los sombreros; también los mantos tienen su alma, su entendimiento y su razón [...]; hoy quiero, deponiendo el encogimiento propio de mi sexo, dar leyes, corregir abusos, reprender ridiculeces y pensar como Vms. piensan, pues aunque atropelle nuestra antigua condición, que es siempre hipócrita de pensamientos, los he de echar a volar para que vea el mundo a una mujer que piensa con reflexión, corrige con prudencia, amonesta con madurez y critica con chiste [...] (Introducción, Pensamiento I, pp. 9-12).

Al igual que su modelo, incluye varias cartas de presuntos corresponsales -mujeres en su mayor parte-que le escriben quejándose de aspectos negativos de su vida familiar y social: una hija desgraciada, la mujer de un marido cortejo, la de un marido anciano, la de un marido miserable, la de un marido tirano, la culta que se siente incomprendida, la que se duele del "decir mal los hombres de las mujeres", etc. aunque no faltan algunas más escritas por hombres, como la de un marido quejoso por la difícil situación en que le colocan una esposa coqueta y su suegra, la de un poeta, la de un hombre enamorado que quiere olvidar a su amada, etc.

Acotando un espacio muy específico, en marzo de 1765, salió El Belianís literario de un "Don Patricio Bueno de Castilla", tras el que se esconde la personalidad de Juan José López de Sedano, autor de la tragedia Jahel, y al que se recuerda especialmente como colector del Parnaso español. De vida muy corta -apenas llegó a 7 números en 4º-, su carácter principal aparece consignado en su elocuente subtítulo: "Discurso andante (dividido en varios papeles periódicos) en defensa de algunos puntos de nuestra Bella Literatura, contra los críticos partidarios del Buen Gusto y la reformación". El autor, pues, se reviste 
de la personalidad de un caballero andante, un "aventurero" (dedicatoria "A la sabia Urganda la desconocida") que sale en defensa de la literatura española contra los críticos modernos, sirviéndose de la retórica y el estilo de las novelas de caballerías, entreverados a veces de cierta dosis de ironía. El prólogo lo dirige a presentar al personaje que va a llevar la voz cantante -"el más esforzado, audaz, valiente, acuchillado y acuchillador caballero que tuvo la Europa y aun toda la Grecia"- y a justificar la empresa, explicando de paso el porqué del título: "... Además del derecho que cada autor tiene de dar a sus obras, como dueño y señor absoluto de ellas, aquel que más bien le viniere en talente, siendo el designio de la presente a justa venganza, desagravio y defensa de los tantos escritores disfamados, opiniones abatidas, prácticas ridículas, huérfanos desamparados y doncellas menesterosas, tirando a este fin toda suerte de cuchilladas, tajos y reveses de pluma a la turba y acompañamiento de críticos de la moda alistados en el formidable y respetuoso bando de la Reformación, no me parece que le podía aplicar título más adecuado, sonoro, altisonante y significativo". Se trata de una singular revista en la que, en clave caballeresca, desarrolla un mordaz repaso crítico por los escritos polémicos periódicos principalmente- aparecidos por entonces, desde una perspectiva ideológica muy afín a la del Escritor sin título. Al igual que él, expresa sus reservas hacia los escritores de vanguardia, pero sin abdicar, por otra parte, de algunas de sus ideas, de modo que por debajo de su españolismo a machamartillo no deja de percibirse al tiempo un parecido afán por renovar la vida social e intelectual española del momento.

De 1767 es una publicación de contenido humorístico-literario que, al menos en su diseño, guarda cierta relación con el grupo de periódicos que estamos considerando: el Bufón de la corte de un "D. Joseph Serna", nombre tras del cual tradicionalmente se ha visto a Francisco Mariano Nifo (Enciso, pp. 296-302). Lo de "bufón" estriba en la condición humorística que recorre la publicación, aun cuando su objetivo primario sea, de forma parecida al Cajón de sastre, reunir textos de autores españoles anteriores (del XVII principalmente, como Quevedo, Salas, Barbadillo, Gaspar Lucas Hidalgo, etc.) de carácter burlesco, en torno a un tema: el amor, el matrimonio, el teatro, etc. Pero fuera de esta perspectiva, la concreción personal no se materializa en más detalles.

Después de él, y tras un paréntesis de catorce años, esta modalidad periodística se reanuda con El Censor, que abre la que atinadamente Guinard ha llamado segunda generación de espectadores. Es la mejor de las publicaciones del género; la de más prolongada existencia; la de más arriesgada crítica, la que concitó más diatribas y persecuciones y, con mucho, la más voluminosa: 161 discursos, aparecidos, con dos paréntesis por motivos de censura, entre 1781 y 1787 . Aunque el nombre de sus autores no aparezca en sus páginas, ya algunos contemporáneos supieron que la responsabilidad última de su publicación recaía en el granadino Luis García del Cañuelo y en el gallego Luis Marcelino de Pereira, dos abogados estrechamente vinculados al llamado grupo de Salamanca, que por entonces se reunía en torno a la condesa de 
Montijo (Jovellanos, Urquijo, Meléndez Valdés, Tavira, Estanislao de Lugo...). Aunque buena parte de lo publicado ha de considerarse obra de ambos -de Cañuelo, principalmente- no fueron los únicos redactores. Jovellanos publicó en él sus dos sátiras "A Arnesto" (núms. 99 y 55), y puede presumirse que fueran suyos tres discursos más (Caso, 1989, pág. 787), Samaniego, escondido bajo el seudónimo de "Cosme Damián" dio a conocer en él un largo discurso sobre el teatro español (no 92), Pedro Antonio Sánchez, con el de "Antonio Filántropo" varios de tema económico (Soubeyroux, 1980) y Meléndez Valdés su romance "La despedida del anciano" ( ${ }^{\circ}$ 154). La presencia de estos colaboradores conocidos y cierta diversidad de ideas y de estilo, ha inducido a José $M$. Caso González a proponer la tesis de que fuera obra de un colectivo; justamente el del grupo de amigos vinculado a la condesa del Montijo, con el respaldo y acaso colaboración del mismísimo Carlos III, favorecedor indudable de la empresa ${ }^{7}$. De todos modos, intervinieran muchos o pocos en su publicación, es evidente que no fue obra de una mano única, por más que se ofreciera al público como expresión de un responsable único: el Censor.

Lo esencial de su retrato moral aparece nítidamente perfilado ya en la dedicatoria al lector y en el discurso primero, aunque ciertos detalles de su personalidad se van desplegando a lo largo de la publicación. Se trata de un racionalista impenitente desde la infancia; un "mártir de la razón", incapaz de acompasar su criterio con nada que ella no le dicte ("ninguna autoridad humana, ni la costumbre, ni la moda más general es capaz de persuadirme lo que mi razón repugna"). De genio vivo y arisco, aunque templado por un humor "algo bufón y jocoso", vehemente, siempre insatisfecho, censor insobornable de todo lo que no le gusta, encuentra en la escritura el medio de desahogar su bilis.

El título que se ha otorgado, como él mimo dice, "anuncia desde luego un hombre poco contemplativo y que hace profesión, no de favorecer errores, sino de combatir con todas sus fuerzas y decir verdades por ásperas y desagradables que sean como sean útiles" (n⿳9 94). Sensible en extremo ante todo lo que le parece recto y ordenado, "cualquier cosa que halle conforme a las leyes de la razón causa en mi una conmoción extraordinaria y me da un placer mayor todavía que la ira que concibo cuando alguna veo que le es opuesta" ( $\left.n^{2} 53\right)$. "Si soy hombre a quien el mal gusto del peinado de un dama incomoda más que a ella el cuidado de conservarlo para el otro día, para eso me encanta una mujer con su peinado bajo, proporcionadamente a su cara y atado el cabello con un lazo bien hecho en una castaña moderada. Si la representación de una comedia de Calderón u de Moreto me forma una apostema, también la simple lectura de El delincuente honrado me hace derramar lágrimas de gozo a un tiempo y de compasión [...] Mas lo que sobre todo me prenda, lo que me enternece sobremanera, lo que me da un placer que no podré fácilmente explicar, es una acción humana y generosa; el olvido de una injuria, un ejemplo algo particular de fidelidad, de gratitud, de amor filial, conyugal o patriótico" (ibid, pp. 98-99).

7. El papel de Cañuelo sería así menor del que se le viene atribuyendo. François Lopez ha manifestado recientemente (1991) sus reservas hacia esta tesis. 
De sus gustos, ideas y ocupaciones añadirá muchas más cosas, por encima o más allá de lo que va expresando discursivamente a lo largo de sus páginas. Como lo agrio de su carácter no le permitió arribar a ningún empleo de honra y de provecho, se dio a las ciencias que le gustaban; a las matemáticas, en primer lugar, "que por no valer en ellas la autoridad dicen admirablemente con mi genio" ( $\left.\mathrm{n}^{\mathrm{Q}} 1\right)$. Ha leído toda suerte de autores, tanto antiguos como modernos; ha estudiado algunas lenguas; ha dado algún paseo por la historia de todos los tiempos y países "y sobre todo he hecho varios viajes por el mundo moral, ya que mis rentas no me han permitido hacerlos por físico" (ibid.). Le gusta comprar libros y manuscritos poco comunes (n⿳⺈ 36). Como hiciera El Pensador, también se manifiesta con acendradas convicciones religiosas: "Yo soy cristiano católico romano por los méritos de Jesucristo, y no por los de mis padres, ni mis abuelos, aunque tengo entendido lo fueron todos como yo; soy muy amante de la religión, y estoy muy persuadido y penetrado íntimamente de la verdad de sus dogmas y santidad de su moral ( $n^{\circ} 23$, pág. 362). Se manifiesta igualmente con un insobornable patriotismo; en nada de lo que hace o escribe busca su bien propio, sino el de su "querida España". Se siente profunda y gratamente impresionado por el talante y la política de Carlos III ( $\left.\mathrm{n}^{\circ} 3\right)$. Gusta de asistir a bailes y frecuentar tertulias, porque en ellos tiene mucho que observar un hombre de su carácter (núms. 6 y 40); por lo mismo le gustan también los cafés, donde se reúnen personas muy variadas ( $\left.n^{\circ} 39\right)$. Sin embargo, su independencia está por encima de todo: "soy un hombre aislado, de ningún cuerpo, de ningún partido, sin conexiones, sin protector" ( $\mathrm{n}^{\mathrm{0}} 5$ ). Incapaz de contemporizar con nada que le disguste, jamás disimula sus opiniones (ibíd). Sus ilusiones las cifra en una vida sencilla y libre, en contacto con la naturaleza, rodeado de un pequeño grupo de amigos y de amigas, sin criados ni etiquetas, dedicado a la lectura, a la conversación, a los paseos por el campo y a algunos deportes asequibles y naturales como la caza y la pesca: es la estampa que brillante y plásticamente expone, introducida por un sueño, en el discurso 39 , uno de los más personales y matizados en clave autobiográfica. A propósito de un sueño que dice haber tenido en el que encontraba un gran tesoro, da a conocer sus aficiones, deseos y aspiraciones, que se resumen en la gran tríada de tiempo, libertad y salud. No desea riquezas ni grandes palacios; tampoco coches ni criados, que sólo le acarrerarían problemas. Le basta lo necesario para pasar la vida sobria y apaciblemente. "Uno de mis mayores placeres es salir al campo al asomar la primavera. No puedo explicar el gozo, la alegría que siento cuando descubro la primera florecita, cuando observo el primer botón que asoma por entre las hojas todavía no bien desplegadas" (pág. 612). Para su comida escogería siempre los alimentos más simples y más acordes con los lugares y las estaciones. Aunque "muy aficionado a los libros, a las pinturas y a las curiosidades de la naturaleza" no por eso tendría una gran biblioteca, una gran galería, o un gran gabinete que ocupasen los salones de un vasto edificio. "Buen gabinete de historia natural es el universo...". Vestiría con sobriedad, evitando cuanto le pudiera distinguir de los demás ("yo quisiera siempre andar de modo que ni me hiciese mi traje despreciable en un café o en el Retiro, ni pareciese un Usía en Lavapiés"). Sus inclinaciones se dirigen más hacia la 
amistad que hacia el amor y el matrimonio: "En nada conozco más bien que mi corazón se ha enervado, que en no gustarme una mujer propia, ni una familia. Los placeres que ésta produce son de un orden muy superior a la capacidad de un alma corrompida. Pero a lo menos, ya que no me casase, tampoco compraría una amiga. Es cosa muy fácil tener mujeres por dinero; pero es también el medio de nunca gozar con ellas el placer verdadero...". El contacto con la naturaleza sería la fuente de sus más grandes satisfacciones y toda su existencia se resolvería en un aurea mediocritas.

Algunos apuntes se refieren a su familia y circunstancias personales: no es viejo ( $\left.n^{0} 40\right)$; de muy cortos caudales ( $\left.n^{0} 7\right)$, vive con un ama cuyo hijo empieza ahora a mascullar el latín ( $\left.n^{0} 36\right)$; todos los miembros de su familia se han señalado por alguna singularidad que los ha distinguido del resto de la gente; su padre, al que admiraba mucho, hombre taciturno y de pocas palabras, poseía el talento particular de "soñar metódica y ordenadamente", al igual que buena parte de los miembros de su familia, incluido él mismo (núms. 50,69 y 161); el hermano mayor de su padre, soñador también, ha dejado escritos algunos discursos que El Censor aprovecha (n 105$)$. Por último, y como ha quedado apuntado, está soltero y no parece particularmente proclive al matrimonio.

Admirador entusiasta del fascinante héroe cervantino, ejemplo sin par de nobleza y altura de miras por encima o más allá de su locura, en su dimensión decididamente combativa se ofrece ante sus lectores como alguien de su misma noble y honrada condición, cuya Dulcinea es la Verdad:

Sí, señores, el Censor es, y lo tiene a mucha honra, muy semejante a un Don Quijote del mundo filosófico, que corre por todos sus países en demanda de las aventuras, procurando desfacer errores de todo género, y enderezar tuertos y sinrazones de toda especie, pertenezcan unos y otros a la materia que pertenecieren. He aquí su manía. Intento verdaderamente loco; ya por la cortedad de sus fuerzas, ya por la debilidad de su armas. Razoncitas, discursitos que cuando más llenan un pliego, y alguna satirilla tan débil como una caña, miren qué batería de cañones, o qué buenos doblones de a ocho para que hubiesen de convencer o persuadir a nadie en el mundo. ¿Hay por ventura lógica u otra retórica que convenza o persuada eficazmente (pp. 10-11).

Por lo demás, y aunque muy bien llevada y desarrollada, sabe que la personalidad de que se ha revestido es un fruto consciente de su personal modo de entender la libertad crítica; no es ni un juego, ni un escamoteo de su personalidad real. Es, sencillamente, la personalidad pública que ha querido asignarse: un uso legítimo del que se podrá discrepar pero no censurar. Con ocasión de la carta de un contradictor que le reprocha trate asuntos de religión y escriba enmascarado, precisa con energía:

Yo hablo al público bajo el nombre de Censor: todo el que quiera puede leer mis discursos; éstos se venden públicamente y en demasiadas librerías; salen a la luz con el examen y aprobación de sujetos muy escriridos y con las licencias necesarias; ;por qué, pues, han de llamar Vms. a esto presentarse al público enmascarado o disfrazado? Ultimamente, sea así como Vms. quiera, ¿qué les importa, vuelvo a preguntarles. 
que yo use de máscara o no use? Convénzame, confúndame si saben; que quizá hallarán en mi más docilidad de la que piensan para confesar y reconocer los errores que se me hagan ver; desengañen al público, si piensan que yo le engaño; si no quisiesen hablar al público, escríbame privadamente, que ninguna de las cartas dirigidas al Censor creo se haya perdido hasta ahora; y he aquí como para nada de esto tienen necesidad de saber quien soy yo en calidad de ciudadano, ni si soy doctor o licenciado, feo o bonito, etc... (n $\mathrm{n}^{\mathrm{o}} 111$, pág. 801).

Al igual que los periódicos anteriores, por sus páginas desfila una extensa y variada gama de personajes. Algunos con una personalidad y un pasado elocuentemente descritos; otros más incoloros y desdibujados, manifestando apenas una pincelada de su existencia. Pero en cualquier caso, una galería que enriquece y matiza la crítica, que la despliega, concreta y actualiza. La primera carta, que aparece en el discurso 6 es de una mujer afligida que le da cuenta de su desventurada historia: casada a los quince años con un hombre muy avaro, vivía una existencia gozosa y despreocupada con el marido dominado y tres cortejos que le sumistraban todo lo que necesitaba; desentendida de los hijos, vivió una vida placentera hasta que en su edad madura y con la belleza ajada, su situación cambia enteramente; los hombres ya no la buscan; es ella la que tiene que regalar a los cortejos y como no dispone de los medios con que agasajarlos, tiene que quedarse en casa. Su consuelo ahora es protestar del estúpido culto que la sociedad concede a la belleza, idea que El Censor comparte y que le mueve a compadecerse de la desgraciada situación de su corresponsal. Luego irán apareciendo otros hombres y otras mujeres; en situaciones no menos difíciles y comprometidas unos, y en circunstancias de menor calado dramático, otros. Con unos sintoniza y se conduele de su triste situación; otros, por el contrario, le sirven para hacer más plástico su rechazo hacia determinadas actitudes frívolas. En cualquier caso, se trata de estampas autobiográficas que enriquecen considerablemente sus observaciones. Así el pobre desventurado a quien amargan el desagradecimiento de sus amigos y la ausencia de recursos para seguir llevando el tren de vida al que estaba acostumbrado $\left(n^{\circ} 7\right)$; el compañero de estudios que le manifiesta su repugnancia por los saludos y abrazos vehementes ( $\mathrm{n}^{\mathrm{O}}$ 14); el petimetre afrancesado que le da cuenta de sus habilidades en materia de cortesía social y de su proyecto de enseñarla abriendo una escuela pública (ibid.); el sinsustancia que, no soportando la pérdida de su perrito faldero, pide al Censor que le facilite otro que lo supla ( $\left.\mathrm{n}^{\mathrm{0}} 22\right)$; el miembro de una Hermandad que se queja de que su párroco-lector del Censores tan estricto que no permite desbordamientos ornamentales en el culto ( $\mathrm{n}^{\mathrm{o}}$ 24); el padre arrepentido y desolado por haber dado una educación rigurosa en exceso a un hijo al que acaba de perder en un combate marítimo (“... mi hijo, señor Censor, se fue al otro mundo sin llevar la menor muestra del cariño de un padre que le amaba, sin embargo, con la mayor ternura...") (no 35); el marido desgraciado por el genio e intemperancia de su mujer, pese a haber sido un matrimonio libremente elegido ( $\mathrm{n}^{\mathrm{0}} 57$ ); el oficial retirado, gran amigo de decir mentiras, que se ufana de su hubilidad para hablar sobre todo lo divino y lo humano aunque se trate de asuntos o lugares que desconoce en absoluto, y que 
reivindica por ello la condición de novelista ("... Yo no se si me engaño; pero no veo qué razón hay para que se me condene a mi y se dejen correr libres tantas novelas como andan por las manos de todos. En efecto, mi conversación puede pasar muy bien por una perpetua novela, y los que me escuchan pueden hacer cuenta que están leyendo u oyendo leer al Lazarillo de Tormes u al Guzmán de Alfarache. Y no se yo que me haga eso demasiado favor. Lo cierto es que algunas veces se halla en mis novelas mucha más invención y mayor nobleza que en éstas y otras obras semejantes. Y así es que muchos se lastiman de que no emplee mis talentos en escribir algunas que, si he de creerlos, harían famoso mi nombre en todo el mundo" (n⿳ 58); la muchacha angustiada por las obscenidades que ha tenido que oír al verse precisada a ir a unos baños para curarse ( $\left.n^{\circ} 78\right)$; el marido enfurecido porque su mujer, rebelde a ser como las demás, no sigue las modas y lleva una conducta rectada y discreta (irónica, claro está) ( $\mathrm{n}^{\circ}$ 95); el hombre que detesta los desafíos ( $\left.\mathrm{n}^{\mathrm{o}} 102\right)$; la mujer que se queja de los comentarios apicarados ("colorados", dice ella) de su marido (no 103), etc. Estampas, muchas de ellas, que cabalmente podrían nutrir acabados relatos novelescos.

Cuando El Censor llevaba ya mucho camino andado, vio la luz, en Mayo de 1786, El Corresponsal del Censor, de Manuel Rubín de Celis, publicación quincenal que, con alguna irregularidad, se prolongó hasta Junio de 1788, alcanzando un total de 51 cartas o números.

El autor, con una ya larga y variada trayectoria de escritor (Urzainqui y Ruiz de la Peña, 1983), plantea la revista como una serie de cartas dirigidas al periódico que, para él -como se desprende de muchos juicios laudatorios ${ }^{8}-$ expresaba la mejor realización crítica del momento. Aunque con un registro irónico generalmente más acusado (como se vislumbra ya en el apunte enunciativo de su primer número, cuando explica que se propone "seguir con Vm. una correspondencia epistolar, toda por este estilo, pues no sé otro", rogándole "haga su merced provisión de paciencia para leer mis delirios, que yo también tengo un grande almacén de ella para sufrir los de otros" (pp. 15-16), su horizonte temático, al igual que su orientación ideológica, están estrechamente ligados a los del destinatario literal de sus cartas. La correspondencia, que no es más que una hábil y original estrategia para modelar sus críticas, se dirige a hacerle partícipe de sus preocupaciones e ideas, a comunicarle las cartas que le dirigen presuntos corresponsales, las conversaciones mantenidas con diversos interlocutores, la traducción de un diálogo a Fenelón que abunda en ideas expresadas por El Censor ( $\mathrm{n}^{\mathrm{0}} 30$ ) y, ocasionalmente, a sugerirle temas sobre los que debe hablar. Con alguna excepción: en el no 25 un lector le envía a él la carta que quiere haga llegar luego a Censor; en el 34, la de otro corresponsal que va dirigida directamente al Censor, y en el 23, es él quien, en vez de dirigirse a éste, escribe a los "señores censores" (de libros) exponiendo sus

8. «...Libertad heroica con que escribe» $\left(n^{2} 29\right.$, pág. 473); «... ¿No ha sido Vm. causa de que varias y utilísimas noticias escondidas en los libros que (por desgracia nuestra) manejan muy pocos, se extiendan prodigiosamente? ¿No ha dado vm. pasto a conversaciones mucho más útiles que las que comúnmente fomentan las Gacetas?...» ( $n^{2} 37$, pág. 606), etc. 
ideas sobre lo que debería ser su verdadera función censoria. En cualquier caso, es una correspondencia que, aunque formulada en términos muy personales y amistosos, nada retóricos, no comporta ni exige respuesta; desde luego, el Censor nunca se hace eco de las cartas que le dirige su colega y discípulo.

El protagonismo crítico, al igual que El Censor, no se limita a su voz de Corresponsal. Como sus predecesores, da cabida también a muchas cartas y colaboraciones; la mayor parte ficticias, como permiten entrever los mismos nombres -casi siempre intencionados- de quienes las firman ("Pedro Mártir", "Simplicio Manso", "María de los Dolores", etc.) aunque hay constancia de que otras son absolutamente reales. En sus páginas publicó Tomas de Iriarte su acerba y divertida crítica en latín macarrónico contra la degenerada filosofía escolástica de la época, titulada Metrificatio invectivalis contra studium modernorum ( $\mathrm{n}^{\mathrm{0}}$ 5), y que suscribió con el seudónimo de "El licenciado Durón de Testa"; en él escribió también Bernardo María de Calzada una extensa epístola en verso contra la Oración apologética de Forner, que aparece en la carta XL con el anagrama de "Lázaro Cadebar de Miranda", identidad que desconocíamos en 1983, cuando Álvaro Ruiz de la Peña y yo publicamos nuestro trabajo sobre el periodista, y que descubre Sempere y Guarinos en el capítulo de "Correcciones y adiciones" de su Ensayo (VI, 1989, p. 231).

Para dar mayor corporeidad a su persona se otorga un nombre propio, "Ramón Harnero", sin duda intencionado por su condición de crítico (lo confirma un corresponsal al dirigirse a él como "señor Don Harnero o don Criba" (p. 183) y se adscribe una personalidad bien definida, con una patria, una genealogía, un carácter, una fisonomía y unos gustos propios. A diferencia, sin embargo, del Censor o del Pensador, es una personalidad sistemáticamente degradada por la ironía y el humor, de modo que ante los ojos del lector se ofrece como un botarante inútil, frívolo y pagado de su condición social. Sólo un ejercicio de inversión permite reconocer, por debajo de esos rasgos, el talante real del crítico que está detrás. En este sentido, guarda una estrecha semejanza con El Apologista Universal que por entonces publica el P. Centeno. Inevitablemente, sin embargo, la nobleza de su misión de crítico y otros rasgos positivos de su persona que van aflorando a lo largo de sus páginas (inteligencia, docilidad, bondad, modestia, etc.), confieren a su personalidad un sesgo contradictorio. O dicho de otro modo, escinden su personalidad en dos caras contrapuestas.

El relato humorístico de su origen, educación y situación familiar le hace muy poco favor. Nacido en el seno de una familia noble y rica, ha sido un muchacho consentido, caprichoso y con una educación más que deficiente. Aunque sus padres le habían puesto un excelente ayo que trató de inculcarle el sentido del trabajo y de la convivencia, y la emulación de las virtudes de sus mayores, sus enseñanzas quedaron enteramente frustradas por su propia indolencia y frivolidad. Como para sus progenitores el estudio era sólo ocupación propia de los miserables que necesitaban buscar un sustento a través de ese medio -según la recomendación que hicieron a su ayo- es un ignorante que 
desconoce hasta las cosas más elementales (v. gr. confunde al historiador Mariana con una mujer). Su biblioteca se reduce a una colección de tonadillas, las comedias de Valladares y Moncín y "al agregado de cuantas jácaras han salido a luz en Madrid de diez años a esta parte" (p. 25).

Cuando empieza a redactar el periódico, goza ya de la privilegiada situación en que le ha colocado el disfrute de su herencia. "Yo, señor mío, heredé a la edad de veinte y cuatro años, por muerte de mis padres, unos mayorazgos, que según dice mi contador rendirán al año no sé que tanto de miles de ducados" ( $\mathrm{n}^{\mathrm{g}} 2$ ). Nada más entrar en posesión de ellos, tomó, entre otras "providencias", la de despedir a los criador viejos que ya no podían serle de provecho, quedándose sólo con los más complacientes y los que le habían enseñado cosas más inútiles. Amigo del teatro, de los paseos y de las mujeres, su existencia se reduce al ocio más improductivo. Todo lo que no tiene que ver directamente con él, le es indiferente. Pródigo y derrochador en sus caprichos, es remiso, sin embargo, a pagar a sus servidores. Tangencialmente consigna que está casado (p. 23), aunque sin explicitar más acerca de su mujer. Más adelante, sin embargo, contradice esta afirmación: en el $\mathrm{n}^{\mathrm{0}} 37$ aparece como soltero y luego, en el 49 , como deseoso de contraer matrimonio, para lo que pide -nueva contradicción- permiso a su padre, quien apelando a prejuicios de casta (punto que se incrimina en ei número), se lo niega por pertenecer la novia a una familia de comerciantes.

En el retrato con que abre la publicación (núms. 1 y 2) se presenta como un habitual de los mentideros madrileños: cafés, Prado, Puerta del Sol ("sitios que frecuentísimamente adorno y en donde me hallará su merced infaliblemente a todas horas"); listo ("no tengo un pelo de sandio" [...] "siendo así que me contemplo [...] hombre de talento"; maldiciente ("tiene [Huerta] tanta habilidad para escritor como yo para decir bien de nadie"); vehemente y seguro de sí ("y creo fuese la primera vez de mi vida que hubiese padecido equivocación". Al igual que sus maestros críticos, otros rasgos de su carácter y condición, o nuevos matices sobre los ya apuntados, irán apareciendo a lo largo de los demás números. En línea con la imagen degradada de su persona, aparece como un hombre poltrón (n 33 ), torpe, que no sabe graduar el mérito de una carta que ha recibido ( $\left.\mathrm{n}^{\mathrm{O}} 34\right)$, metomentodo, envidioso ( $\mathrm{n}^{-3}$ ) , y tan profundamente conservador que ve con alarma la introducción de las ideas modernas y aun desprecia a Voltaire, Rousseau y los espiritus fuertes $\left(\mathrm{n}^{\circ} 4\right)$. La carta que en el $\mathrm{n}^{\mathrm{0}} 16$ dirige, reprochándole su conducta, a un primo suyo -que, para un lector avisado sería el prototipo del hombre ilustrado- apura, por contraste, su condición de persona frívola, vaga, inculta y soberbia. Pero es obvio que todo ello responde al "genio bastamente burlón y satírico" que confiesa tener $\left(\mathrm{n}^{\mathrm{o}}\right.$ 33). En contrapartida, cuando abandona su faz irónicamente burlona, aparece con muchos aspectos positivos, dando una imagen mucho más noble y dignificada de su persona. En esta línea positiva, junto a la modestia, docilidad y buen sentido, cabe destacar la sensibilidad de que hace gala para reconocer la vida sencilla, sobria y honesta del pueblo bajo $\left(n^{\circ} 17\right)$ y la inteligente percepción, muy rousseauniana, de los pueblos primitivos de América ( $\left.\mathrm{n}^{\circ} 12\right)$. Aparece 
también como fiel hijo de la Iglesia (núms. 27 y 42), bien informado en cuestiones teológicas (nums. 27 y 28); que ha gozado de excelente salud, aunque últimamente la tiene más quebradiza (núms. 21 y 31); propenso a la melancolía ( $\mathrm{n}^{\circ} 47$ ); sin carrera, pero con estudios suficientes para dirimir cuestiones de moral con un teólogo (núms. 27 y 34) o para criticar sólidamente desviaciones y abusos en materia religiosa; muy dado a salir de cuando en cuando en solitario a hacer un poco de ejercicio por los paseos que hay extramuros de la corte "meditando sobre las diversas locuras que acometen los hombres" ( $\left.\mathbf{n}^{\circ} 20\right)$. Y, al igual que el Censor, se confiesa en plena sintonía con la política de Carlos III (n²9).

La descripción, muy caricaturesca, de su persona, aparece en el $n^{2} 10$, a raíz del encuentro, en una tarde de toros, con un lector, gran admirador del periódico, que se dirigió a él para identificarle.

“... Se llegó a mi un hombre de nariz aquilina, ojos garzos, color cachumbo y en su vestir vaciado a la antigua, el cual con muchos reconcomios y contorsiones me preguntó si yo era el Corresponsal del Censor, porque según las señas que le habían dado de mi persona, tales como nariz larga, ojos chicos y vivos, maltratado el semblante de las viruelas, rizos flotantes, cargado de espaldas, estatura mediana, de aspecto melancólico, y en el andar aire de esportillero hecho y derecho, no podía ser otro que esta misma mesmedad. Si señor, le respondí, yo soy ese propio Corresponsal" (pp. 141-142).

El diálogo que tiene con él y que transcribe a continuación, le permite entre bromas y veras mejorar un tanto esta imagen ofreciéndose, desde los ojos de su fervoroso admirador, como un excelente y atinado crítico (“... cosa más salada ni más chusca que sus cartas no la he leído en mi vida. ¡Con qué gracia dice vmd. un millón de desvergüenzas! ¿Con qué tunería se deja caer a plomo sobre más de cuatro que ni aun por el talón se creían vulnerables!") y mucho más claro que el Censor.

Su trabajo periodístico también aparece mencionado con parecida ambigüedad humorística. Aunque por una parte dice que le supone un gran esfuerzo y que no ha cosechado sino sinsabores y bochornos, hasta el punto de pensar abandonarlo para ocuparse en tareas más gratificantes (núms. 14, 16, 26 y 36), por otra, se aferra a él, jactándose de tener una respuesta social muy superior incluso a la del mismo Censor (núms. 12 y 37).

De las numerosas cartas que recibe, hay unas cuantas que merecen destacarse por sus valores autobiográficos y literarios. En el no $\mathrm{n}^{\circ}$, la denuncia de la mala educación que las madres dan a sus hijas, tiene como protagonista a "Leocadia Matute", quien, a vueltas de la petición de ayuda para que le muestre el medio para salir de su miserable y fatigado estado de soltería, expresa su frustración y su ira por no haber conseguido el único objetivo que se marcó en la vida: casarse. Es la historia de una mujer de mundo, frívola y alocada, a la que en el momento de escribir domina un vivo sentimiento de envidia al ver que otra mujer, enteramente distinta a ella, modesta y hogareña, acaba de contraer 
matrimonio con un hombre rico, juicioso y buen cristiano con el que lleva una pacífica vida de felicidad conyugal. Una historia complementaria es la que se narra, con idéntica retranca irónica, en el número siguiente. Ahora quien le escribe es un sujeto de parecida condición, sólo que en masculino: "Simplicio Manso". Tan insustancial como ella, su carta relata la historia de su vida conyugal con "doña Prudencia Sola", en la que fácilmente se reconoce el paradigma de mujer para la mentalidad ilustrada (hacendosa, buena ama de casa, preocupada por la educación de los hijos, etc.) aunque, según él, chapada a la antigua: lo que, pese a haberle proporcionado mucha felicidad, le ha avergonzado siempre. Ahora, cuando escribe la carta, expresa su satisfacción por ver que, gracias a ciertas amistades, ha cambiado de conducta y es tan marcial y tan petimetra como las demás.

En el n" 9 aparece la extensa y patética carta de "María de los Dolores", una muchacha joven, bella y bien educada, que le hace partícipe de su triste historia de amor. Hace tiempo que un joven digno de todo su amor le declaró con la mayor modestia el suyo. Decidida a casarse con él, sus ilusiones se vieron frustradas por la inflexibilidad de un tío suyo con el que vivía, que le preparó como esposo al hijo de una viuda rica, un hombre despreciable por el que no sentía sino repulsión. Como ella no aceptó sus planes de matrimonio, la relación cambió enteramente, y lo que había sido afecto y protección se transformó en odio y malos tratos. Y cuando tres años después aquél falleció, ni siquiera tuvo el consuelo de poder atenderle en sus últimos momentos. Sin un céntimo para vivir y sin techo donde cobijarse, pues el tío legó todos sus bienes para misas y obras pías, vive ahora en casa, justamente, de un amigo del propio Harnero.

La historia de "Don Alberto Naranjo y Peralta" ( $\left.n^{\circ} 12\right)$ es enteramente diferente. Se trata de un petimetre que le participa su deseo de casarse con una mujer acomodada a su modo de pensar e inclinaciones "esto es, educada galanamente". Pensando en que la aludida "doña Leocadia Matute" puede convenirle, le envía una extensa noticia de su persona y circunstancias "para que Vmd. se sirva trasladar este retrato a los delicados ojos de Madama y tratar nuestro conyugio, que apetezco con las mayores veras". Traza así a continuación, en primera persona, su personal autobiografía, que no es más que la de un vanidoso muchacho, mayorazgo de una noble y rica familia madrileña, inculto y sinsentido, que bien podría encarnar cualquiera de los personajes que por entonces satiriza Jovellanos en El Censor.

La carta más patética y desarrollada con mejor tempo narrativo es la extensa y dolorida confesión de una monja septuagenaria, "María Josefa de las Angustias", que publica en el n⿳ำ 13, para denunciar los ingresos en religión de muchachas jóvenes sin verdadera vocación. Es una triste historia de frustraciones y desajustes vitales. Atraída desde muy joven por el amor, a los diecisiete años se enamoró apasionadamente de un primo suyo con el que anhelaba, de común acuerdo, casarse. Pero sus padres, insensibles a los gritos de la razón, deshicieron el proyecto y forzaron "impía y violentamente nuestro destino". 
Casaron a su primo con su hermana mayor y a ella, tras una breve temporada en el campo, la destinaron a la vida religiosa, en un convento del que era superiora una tía suya. Pero la angustia por la separación y boda de su primo le acompañó toda la vida. Los primeros tiempos de su vida religiosa fueron de oración, mortificación y serena obediencia a la regla conventual; pero las frecuentes visitas de parientes y la proporción que el cargo de su tía le daba fueron excitando en ella el recuerdo del mundo que había dejado. Pasado un tiempo, se enteró de que su primo venía con su familia a vivir en la misma ciudad. Fue a visitarla, y con la visita, rebrotó el amor. A partir de entonces le empezaron a fastidiar los ejercicios religiosos y entró en un prolongado estado de indolencia espiritual. Sólo deseaba estar con su primo. Envidiaba el matrimonio. Tiempo después, aquél murió arrepentido, y ella empezó a sentir también el horror de sus pecados. Ahora, cuando ya no hay solución para su vida desencantada, escribe al periódico para que alerte a los padres y no violenten la voluntad de sus hijos. Y termina con estas conmovedoras palabras: "Ojalá que esta confesión pública de mis maldades y el débil sonido de mi voz penetre sus corazones y los haga bien mirados y prudentes en una materia en que se cometen tan grandes pecados de consecuencia" (pág. 216).

Buenos argumentos también para otras tantas novelas, con situaciones y conflictos que apuntan decididamente hacia el relato psicológico moderno.

A completar lo que algunos llamarán entonces la trinca censoria vino $E l$ Apologista Universal, una tan brillante como efímera revista -apenas 16 números- que se publicó entre mediados de 1786 y principios de 1788 . Fue obra del agustino Pedro Centeno, bien conocido por el injusto proceso inquisitorial al que fue sometido y de cuyas resultas, según la tradición común resellada por Llorente, murió loco, y de Joaquín Ezquerra, uno de los fundadores del Memorial literario, aunque este último parece que actuó tan sólo como editor (Urzainqui, 1985). Dirigida, como certeramente consigna Sempere, a "corregir el mal gusto, el chabacanismo, la irregularidad, pedantería y demás vicios de los escritores" (1787, pág. 195) y como el propio periódico irónicamente refleja en su título -_"Obra periódica que manifestará no sólo la instrucción, exactitud y bellezas de las obras de los autores cuitados que se dejan zurrar de los semicríticos modernos, sino también el interés y utilidad de algunas costumbres y establecimientos de moda"- fue servida como el fruto del esfuerzo apologético de su autor, si bien desde un transparente y continuado registro irónico. O sea, los motivos, de sus defensas son justamente los aspectos que quiere criticar. $Y$ ahí radica fundamentalmente, en esta condición, su creación autobiográfica, pues apenas ningún otro aspecto de su persona o circunstancias aparecen reflejados. Se ofrece exclusivamente desde el ángulo de su labor apologética: explicando los motivos por los que la emprende, las reacciones que observa en el público, las satisfacciones o los sufrimientos que le ocasiona, las amistosas relaciones que establece con sus clientes (de los que se autoproclama "patrono"), las "reglas" que les prescribe para saber defenderse, las obligaciones de su cargo, etc. Sólo muy de cuando en cuando alude, utilizándolos como pretexto para sus incriminaciones irónicas, a algún paseo que realiza por las 
calles de Madrid, a alguna visita a la librería de Castillo, a los Reales Estudios de San Isidro o a la calle Jacometrezo para comprar un mono. No renuncia, sin embargo, a otorgarse una identidad. Aunque la solapa en el primer número bajo las iniciales P.C.G., la declara ya en el segundo resolviéndolas con su nombreseudónimo completo: "Policarpo Chinchilla Galiano". Tampoco renuncia a dar alguna pincelada sobre su persona: no tiene las narices largas ni es religioso, como habían propalado sus enemigos ( $\left.n^{\circ} 6\right)$. Incluso da la pista, igualmente irónica e intencionada, de su domicilio: en la calle del Desengaño, frente de la Buena Dicha (n² 2).

Para acomodarse a las pautas de sus predecesores (a los que envidia por ello, según consigna humorísticamente en el $\mathrm{n}^{\mathrm{Q}} 14$ ), introduce alguna que otra carta. Pero son tan ficticias y tan irónicas como el resto, siendo sus corresponsales: un duende que le avisa de los ataques que quieren lanzar contra él, un representante de la "Academia lucífuga" que manifiesta el alcance y difusión que está teniendo la revista y dos de sus "clientes" favoritos, Patricio Redondo y Forner. Pero son cartas sin elementos autobiográficos, teniendo como único objetivo permitirle desarrollar más vivamente los temas de que trata.

Detenido en el cajón del censor el n⿳⺈ 17 por las personalidades (ataques personales) contenidas contra Forner, y sobreseído finalmente el expediente, su existencia terminó con el número 16. Sin embargo, su espíritu y su carácter se prolongaron en dos publicaciones inmediatas, El Teniente del Apologista Universal, suscrito por "D. Eugenio Habela Patiño, Cliente y comisionado especial suyo" (1788) y El Corresponsal del Apologista Universal (1787).

En el Prólogo del Teniente aparece el autor como un escritor sin oficio ni beneficio, cliente del Apologista, a quien va a visitar el día de Pascua. Éste, después de decirle el gran trabajo que tiene, le pide que le ayude en sus apologías. Aceptada la misión, le encarga por el momento algo fácil. "Comenzarás a ejercer tu cargo defendiendo la Suma filosófica del P. Roselli; cosa facilísima pues está fuera del día con defender y exaltar la Filosofía escolástica, y hacer esto en España es cosa aun más hacedora que el alabar Atenas en Atenas, proverbio de las cosas fáciles..." (pp. 6-7). Y de eso se trata: de hacer una acerada crítica de este texto paradigmático de la escolástica del momento, de la que se habían publicado ya los dos primeros tomos, apelando al mismo registro irónico que nutrió su Apologista. El camino que sigue, muy expeditivo, es dar a conocer un cuadernillo que oportunamente llega a sus manos titulado Suplemento a la Suma Filosófica: Primera salida de D. Quijote, segundo de este nombre, que no es ni más ni menos que un relato paródico de las andanzas de la tal obra configurada como un D. Quijote del mundo filosófico. A partir de ese momento, la primera persona deja paso a la tercera -el ensayo a la novelasin que quede ya espacio para el yo-cliente del Apologista. Este relato, en cuatro capítulos, tiene su continuación en forma de Apéndice a la primera salida de Don Quijote el escolástico, suscrita igualmente por Eugenio Habela Patiño, y publicada en la misma imprenta de Espinosa en 1789. Todo hace pensar que este "Habela Patiño" no es sino otro nombre de guerra del mismo P. 
Centeno. Por si no bastase la coincidencia entre el estilo y las ideas de ambos con los del Apologista, una pasaje del mismo ayuda a corroborarlo. En un diálogo mantenido por el protagonista con un capitán dice tener el encargo de hacer una sátira contra el Apologista y su Teniente y apostilla entre paréntesis: "si es que el Apologista y su Teniente son dos. Dos son -respondió el capitánaunque cada uno de ellos hallará su misma persona en la persona del otro por la regla de amicus est alter ego..." (pág. 95).

El Corresponsal del Apologista se limita, en lo que conocemos, a un sólo número, aparecido cuando el Apologista iba ya por su número 14 (Barrero, 1990). El desconocido autor, que parece haberse inspirado en El Corresponsal del Censor, plantea su obra como una correspondencia para corroborar los objetivos críticos del Apologista, por el que siente una gran admiración ("ver si puedo hacerme parte en la utilidad de su proyecto") y defenderle de la críticas levantadas contra él ("contra todo el torrente de sus rivales"). Y en ello estriba todo su ejercicio de autocreación.

Por razones todavía no suficientemente documentadas, El Censor desapareció de la escena pública a mediados de 1787. Pero el espíritu que había alentado la empresa siguió vivo, como hemos visto en los periódicos anteriores, y tuvo una inmediata, aunque efímera, continuación en El Observador de José Marchena, a la sazón joven estudiante en la universidad de Salamanca (López, 1966). "Esta obra periódica -declara el joven redactor- será muy semejante a la que salía antes con el nombre de El Censor. La pérdida de sus preciosos discursos es irreparable. Pero me lisonjeo de que si mi habilidad es inferior a la suya, mi amor a la verdad y, osaré decir, mi probidad es igual a la de este honrado autor" ( $\mathrm{n}^{\circ} 1$ ). Con su modelo coincide en la conformación de una personalidad de observador crítico de la sociedad, valiente y batallador, de espíritu libre, comprometido sólo con la verdad, y dispuesto a enfrentarse con los prejuicios más inveterados y las posturas más conservadoras; unos rasgos en los que, aun cuando no falte cierta dosis de autocreación, se reconocen los ingredientes básicos que marcaron su agitada trayectoria humana y política:

... A Dios gracias tengo lo basante para mantenerme sin necesidad de la ayuda de ningún poderoso. Esto, junto con mi orgullo natural ha hecho que en toda mi vida se me haya visto en la antesala de ningún magnate hambreando su protección. No soy ni eclesiástico, ni togado, ni militar, ni casado tampoco, ni tengo ningún empleo por Rey ni Roque; de manera que no puedo tener predilección a una clase de hombres, sino en tanto que es más útil a la sociedad que las demás [...] Mi modo de pensar es tan extravagante, que en viendo que muchos hombres adoptan una opinión, comienzo al instante a desconfiar de ella, por cierta que me haya parecido hasta entonces. Yo no sé cómo es: yo huyo de abrazar opiniones singulares; y, sin embargo, las mías son otras tantas paradojas para el mayor número de aquellos a quienes se las comunico [...] No sé si es mal humor, si lo qué es, yo suelo observar mil fealdades en donde otros no notan sino belleza, y al contrario $[\ldots]\left(\mathrm{n}^{\circ} 1\right.$, pp. 4-6).

Luego, tras explicar sus gustos y su manera de pensar en el terreno intelectual (aspecto de su autobiografía en el que pone particular empeño explicativo), añade, refiriéndose a su carácter: "Naturalmente es melancólico y 
fácil de alterarse. Esto, junto con un genio observador, me ha causado y me causa a cada paso mil pesadumbres. En las cosas mismas en que otros hallan mil motivos de placer, hallo yo doce mil de pena...". Sensible en extremo a la miseria y a la desigualdad social, rubrica su retrato con esta magnífica declaración de principios: "Amando la verdad no la digo siempre, pero jamás he dicho lo contrario. Callar la verdad es a lo más una cobardía; desmentir sus sentimientos es una vileza y una traición" (pág. 12). Estos presupuestos que, efectivamente, puso en práctica ya desde el comienzo de la publicación, determinaron que la censura le impidera pasar más allá del número 6, el último que salió, y que la Inquisición la condenara in totum en 1791.

A diferencia del Censor, no incorpora ninguna carta; probablemente porque lo efímero de su existencia no le dio tiempo suficiente para recibirlas o prepararlas para la edición, pues en su diseño sí que estaba el darle cabida (en su caso, sólo a las reales).

Por entonces vio la luz El Duende de Madrid, obra de uno de los fundadores del Memorial literario, Pedro Pablo Trullec, oscura personalidad -era Portero de la Cámara de Castilla- del que sólo nos ha llegado esta obra impresa, y con el que colaboró un hermano de Montengón, clérigo de los Cayetanos (Urzainqui, 1990). Sus siete números se publicaron irregularmente desde finales de 1787 a mediados de 1788 . Su formato y estructura, que no sus ideas, difieren bastante de los demás espectadores, haciéndolo particularmente original. El autor desdobla su personalidad crítica en dos voces diferentes: la de un duende observador que se constituye en portavoz de una pequeña comunidad de duendes críticos, y la del encargado de hacer llegar a los lectores el texto facilitado por aquél, un personaje muy popular del Madrid de la época, real y no ficticio, como recientemente ha demostrado Andioc (1992), y encargado también de distribuir y vender la revista: D. Benito, quien es quien suscribe el prólogo presentándose a sí mismo y a la publicación. Cada número se articula así en dos partes: una introducción en dos o tres páginas en las que $\mathrm{D}$. Benito manifiesta cómo llegó hasta él el papel que va a dar a continuación y luego el discurso propiamente dicho, que puede ir desde una "defensa de los zapateros" a una "Respuesta imparcial al censor de los Teatros de Madrid". A partir de no $\mathrm{V}$, sin embargo, ya no intervienen los duendes y $\mathrm{D}$. Benito se transforma en Agente de negocios.

Uno y otro ofrecen diversos rasgos autobiográficos. D. Benito se presenta como un buen hombre, de origen pasiego, inocente y medroso, que ve alterada su tranquila existencia por la irrupción de esta nueva misión ("mi empleo no me da un rato de descanso" ( $\mathrm{n}^{\circ} 3$ ) que obedece a regañadientes. El duende, por su parte, asegura que es un "duende de bien y del gremio de aquellos duendes de estimación que miramos con celo por el bien público", cristiano ("porque has de tener entendido que los duendes de mi clase somos cristianos católicos") y "de carne y hueso como tu, aunque de estructura más fina y delicada". Aunque sean del otro mundo, Dios los envía a éste "para ser inseparables de los hombres, acompañarles a todas partes y hacerles reflexiones sobre todas las 
cosas criadas, leyes, costumbres y policía de las gentes", por lo que, más que Duendes, prefieren llamarse "Genios, es a saber (para lo que entiendas) talentos y discernimientos sobresalientes de los hombres" (pp. 12-13). En tanto que duende, transforma su fisonomía e indumentaria siempre que quiere, y actúa como enviado de la junta de los Duendes.

La última revista que se afilió a esta línea de autocreación fue El filósofo a la moda (1788), adaptación libre y parcial del Spectador inglés por el intermedio de una versión italiana de Cesar Frasponi, que lo es a su vez de otra francesa. De autor anónimo, fue publicándose en entregas sucesivas, hasta alcanzar un total de 36 números en 60 lecciones. Su origen foráneo queda consignado en la portada - "Obra periódica que se distribuye al público los lunes y los jueves de cada semana. Sacada de la obra francesa intitulada $L e$ Spectateur ou le Socrate moderne"- y explicado en el prólogo al "Amigo lector", donde manifiesta su admiración por el modelo inglés y su propósito de seguirlo, a través de las dos versiones extranjeras, pero adaptando las ideas a la realidad española:

Amigo lector: Acaso no habrá habido jamás ninguna obra ni antigua ni moderna que haya hecho tanto ruido en el país donde nació como Le Spectateur. El público de Francia la disfrutó en Papeles periódicos intitulados Discursos, de los que llegaron a despacharse veinte mil ejemplares en un día, y consecutivamente se hicieron otras muchas impresiones. Cesar Frasponi compuso sobre Le Spectateur su Filósofo a la moda, dando a los discursos el título de Lecciones, y omitiendo o mudando las que le parecieron algún tanto libres. Yo me he propuesto hacer lo mismo, no porque en el trabajo de Cesar Frasponi no halle ninguna palabra capaz de escandalizar el oído más escrupuloso, sino para adaptarme a este público, que acaso no leería de buena gana ciertas proposiciones hijas de la envidia de muchos escritores extranjeros. Yo, pues, bajo el título de Filósofo a la moda o Maestro universal pondré aquí aquellas lecciones que me parecieron útiles, suplicando a mis lectores disimulen los defectos de estilo, en consideración a que me he determinado a escribir para utilidad suya y no por vanagloria mía. Vale.

Y en efecto, la adaptación es tal que el lector, de no estar advertido por el autor, creería que se halla ante una obra original, pues las situaciones, nombres, autores, periódicos y referencias geográficas, con pocas excepciones, remiten al Madrid de la época. De todos modos, y hasta tanto no se hagan un cotejo de la obra con sus fuentes, no se podrá saber el grado de originalidad que llegó a tener.

Cada número reúne una o varias lecciones sobre diferentes temas (la moda, la superstición, la ociosidad, la educación, la frivolidad, la adulación, la pereza, etc.) al hilo de las cuales incluye, como los anteriores, cartas que le remiten los lectores, normalmente breves y compendiadas por el autor, así como algunas anécdotas y casos para dar un sello más vivo y dinámico a la publicación y acentuar la carga ejemplarizante. La galería de sus corresponsales es muy amplia: desde un médico que, por serlo, cree verse afectado por todas las enfermedades que estudia ( $n^{\circ} 2$ ) hasta una adolescente de 13 años que le pide consejo para poder casarse $\left(\mathrm{n}^{2} 20\right)$. 
El anónimo Filósofo, que se expresa siempre en primera persona -una veces en tono jocoso y otras, las más, en tono grave- dice bastantes cosas de si mismo; pero más de sus ideas y actitudes que de su vida, aunque no faltan referencias a sus paseos, visitas, tertulias, encuentros, etc. "Soy más sensible a una carta en que habla la naturaleza que a una en que sobresalga el ingenio" ( $\mathbf{n}^{\circ}$ 10, pág. 181). "No hay autores que lea con más gusto que aquellos que representan a la Naturaleza bajo diferentes aspectos, que describen la variedad de costumbres que han sido de moda en diferentes tiempos" (pág. 31). "No hay cosa en el mundo que desee con más ansia que una paz permanente entre todos los príncipes de Europa" (pág. 53), etc. Confesiones, especulaciones, que ahorman su personal forma de individuación, por encima de sus concreciones españolizadoras, en los perfiles caracterizadores de su fuente y modelo: un hombre reflexivo, "observador de todo lo que hay de nuevo, extraño y singular en el mundo" ( $\left.\mathbf{n}^{\circ} 29\right)$ y hondamente preocupado por elevar el nivel moral e intelectual de la sociedad.

Cuando él cesó, todavía, tuvo la oportunidad de seguir caminando Don Quijote el Escolástico. Pero ya empezaban a correr malos vientos para la prensa periódica, especialmente para la prensa crítica. El decreto del 24 de Febrero de 1791, inscrito en la energía política de cordón sanitario impuesta por Floridablanca, acabó, momentáneamente, con ella. Y cuando poco a poco volvió a reanudarse, a partir de 1792 , el espacio que antes había ocupado, con intermitencias, la prensa crítica, estaba ya cerrado, y sólo volvería a abrirse muchos años después cuando la liquidación del Antiguo Régimen diera nuevos impulsos a la libertad de expresión. Pero la obra estaba hecha. Y con ella, la conformación de un singular universo analítico en el que a la palabra crítica se unieron, brillante y agudamente, un peculiar modo de articularse el escritor-lo diré con la fórmula clásica del maestro Marichal- "a sí mismo con su mundo histórico coetáneo", los mecanismo y estrategias, siempre fecundos y estimulantes, de la autobiografía en la que se reconoce y espeja, por encima o más allá de sus concreciones particulares, el espíritu mismo del siglo XVIII, con sus aspiraciones, luchas y tensiones.

\section{BIBLIOGRAFÍA}

AGUILAR PIÑAL, Francisco. 1978. La prensa española del siglo XVIII, Diarios, revistas y pronósticos. Madrid, C.S.I.C. (Cuadernos bibliográficos, $\mathrm{n}^{\mathrm{0} 35}$ ).

ANDIOC, René y Mireille (eds.) 1967. Leandro Fernández de Moratín, Diario (Mayo 1780 Marzo (808), Madrid, Castalia.

ANDIOC, René. 1992. «D. Benito, mythe ou réalite?», Archivos do Centro Cultural portugues, XXXI, Lisboa-París, pp. 183-197.

ANDRÉS, Juan. 1793. Origen, progresos y estado actual de toda la literatura. Obra escrita en italiano por el Abate D. Juan Andrés y traducida al castellano por D. Carlos Andrés, Madrid, Imp. de Sancha, VI.

Amigo y corresponsal del Pensador, El. Su autor Don Antonio Mauricio Garrido. Papel periódico que saldrá cada quince días en el viernes de cada semana, Madrid, Francisco Xavier García, 1763. 
Apéndice a la Primera salida de Don Quijote el Escolástico, Madrid, Gabriel Espinosa, 1789. Apologista Universal, El [Madrid], Imprenta Real, 1786-1788.

BARRERO PÉREZ, Oscar. 1990. «La recuperación de un periódico del siglo XVIII: El Corresponsal del Apologista», en Periodismo e Ilustración en España. Actas del Congreso Internacional sobre el Periodismo español del siglo XVIII (1989), Estudios de Historia Social, núms. 52-53, Enero-Junio, pp. 61-64.

Belianís literario, El. Discurso andante (dividido en varios papeles periódicos) en defensa de algunos puntos de nuestra Bella Literatura, contra todos los críticos partidarios del Buen Gusto y la Reformación. Su Autor Don Patricio Bueno de Castilla, Madrid, Joaquín Ibarra, 1765.

BRUSS, Elizabeth. [1976] 1991. «Actos literarios», en La autobiografía y sus problemas teóricos. Estudios e investigación documental, Anthropos (Suplementos, 29), Diciembre, pp. 62-79.

BUENO, Gustavo. 1966. «Sobre el concepto de ensayo», en El P. Feijoo y su siglo, Cuadernos de la Cátedra Feijoo (Oviedo), 18, I pp. 89-112.

El Bufón de la Corte, El. Por Don Joseph de Serna. Madrid, Gabriel Ramírez, 1767.

CASO GONZÁLEZ, José Miguel. 1989. El Censor, Obra periódica comenzada a publicar en 1781 y terminada en 1787. Ed. Facsímil, con prólogo y estudio de - Homenaje de la Universidad de Oviedo al Rey Carlos III en el bicentenario de su muerte, Universidad de Oviedo, Instituto Feijoo de Estudios del siglo XVIII.

- 1991. «El Pensador, ¿periódico ilustrado?, en Periodismo e Ilustración en España, pp. 99-106.

Censor, El. Obra periódica, [Madrid], [s.i.], 1781-1787.

Corresponsal del Apologista, [Madrid], [s.i.], [s.a.] [1787].

Corresponsal del Censor, El, [Madrid, Imprenta Real], [1786-1788]

Duende político que da cuenta de los más presentes negocios, y anuncia los más críticos futuros desta Monarquía en los años de 1735 y 1736 , El. Ms. A del Duende (Biblioteca del Instituto Feijoo de Estudios del Siglo XVIII)

Duende de Madrid, El. Discursos periódicos que se repartirán al público por mano de Don Benito, Madrid, Pedro Marín, 1787.

EGIDO, Teófanes. 1968. Prensa clandestina española del siglo XVIII: «El Duende crítico», Valladolid, Universidad.

ENCISO RECIO, Luis Miguel. 1958. Nipho y el periodismo español del siglo XVIII. Valladolid, Universidad.

ESCOBAR, José. 1982. «El ensayo en las revistas españolas del siglo XVIII: espíritu crítico y caracterización del autor», Actas de IV Congreso Internacional de Hispanistas, Salamanca, Universidad, pp. 483-490.

Escritor sin título, El. Discurso primero dirigido al autor de las Noticias de moda, sobre lo que nos ha dado a luz en los días 3, 10 y 17 de Mayo. Traducido del español al castellano por el licenciado don Vicente Serraller y Aemor. Madrid, Manuel Martín, 1763.

Filósofo a la moda o el Maestro Universal, El. Madrid, [s.i.], 1788.

GARCÍA PANDAVENES, Elsa (ed.) 1972. «El Censor» (1781-1787). Antalogía, Barcelona, Labor. 
GONZÁLEZ TROYANO, Alberto. 1990. «Aproximación a La Pensadora gaditana», en Periodismo e Ilustración, pp. 261-264.

GUINARD, Paul F. 1973. La presse espagnole de 1737 à 1791. Formación et signification d'un genre, París, Centre de Recherches Hispaniques.

GUSDORF, Georges. [1948] 1991. «Condiciones y límites de la autobiografía». Publicado originalmente en Formen der Selbsdarstellung. Analekten zu einer Geschichte des literarischen Selbsportraits (Berlin, Duncker y Humblot, 1948, pp. 105-123), lo ha traducido y publicado Angel G. Loureiro en La autobiografía y sus problemas teóricos cit, pp. 9-18.

HENDRIX, W.S. 1922-1923, «Quevedo, Guevara, Lesage and the Tatler», Modern Philology, XIX (1921-1922), pp. 177-186.

KITTS, Sally-Ann, 1990. «La prensa y la polémica feminista en la España del siglo XVIII», en Periodismo e llustración, pp. 265-273.

LÓPEZ, François. 1966. «Les premiers écrits de José Marchena», en Mélanges à la memoire de Jean Sarrailh, Paris, Centre de Recherches de l'Institut d'Études Hispaniques, I, pp. 55-67

- 1991.«Luis Cañuelo, alias Elcensor, ou le pauvre diable», en Mélanges offerts à Paul Guinard, II, París, Ibérica, pp. 145-157.

MARICHAL, Juan [1957] 1984. Teoría e historia del ensayismo hispánico, Madrid, Alianza Universidad, 1984, pp. 13-14 [1 ${ }^{\text {a }}$ ed. titulada La voluntad de estilo, 1957].

LEJEUNE, Philipe. 1957. Le pacte autobiographique, Paris, Seuil

— [1957] 1991. «El pacto autobiográfico» en La autobiografía y sus problemas teóricos cit, pp. 47-61.

Murmurador imparcial (El) y observador desapasionado de las locuras y despropósitos de los hombres. Obra periódica que ofrece en obsequio de las personas de buen gusto Don Francisco mariano Nifo, Madrid, Francisco Xavier García, 1761.

Observador, El. [S.I., s.i., s.a.] [1787]

Pensador, El. Por Don Joseph Álvarez y Valladares. Madrid, Francisco Xavier García, 1764.

Pensadora gaditana, La. Por Doña Beatriz Cienfuegos, Madrid, Francisco Xavier García, 1763.

Pensador matritense, El. Discursos críticos sobre todos los asuntos que comprende la Sociedad civil. Con Real privilegio que tiene D. Pedro Ángel de Tarazona, Barcelona, Francisco Generas [s.a.]

SAIZ, Ma Dolores. 1983. Historia del periodismo en España 1. Los orígenes. El siglo XVIII, Madrid, Alianza Editorial.

SEMPERE Y GUARINOS, Juan. 1785-1799. Ensayo de una biblioteca de los mejores escritores del reinado de Carlos III, Madrid, Imprenta Real.

SOUBEYROUX, Jacques. 1980. «Una figura clave de la Ilustración española: Pedro Antonio Sánchez (don Antonio Filántropo)», en Actas del Sexto Congreso Internacional de Hispanistas, Toronto, University of Toronto Press, pp. 723-726.

Teniente del Apologista Universal, El. Por D. Eugenio Habela Patiño, Cliente y comisionado especial suyo, Madrid, Antonio Espinosa, 1788.

URZAINQUI, Inmaculada, RUIZ DE LA PEÑA, Á 1*:aro. 1983. Periodismo e ilustración en Manuel Rubín de Celis, Oviedo, Centro de Estudios del siglo XVIII-Consejería de Cultura del Principado de Asturias. 
URZAINQUI, Inmaculada. 1985. «La censura de La conquista del Parnaso y el fin de El Apologista Universal (1786-1788), Archivum, XXXIX, pp. 385-416.

- 1991. «Los redactores del Memorial literario (1784-1808)», en Periodismo $e$ Ilustración en España, pp. 501-516. 